\title{
Repowering Industrial Combined Heat and Power Units: a Contribution to Cleaner Energy Production
}

\author{
Miroslav Variny*, Marianna Kšiňanová \\ Department of Chemical and Biochemical Engineering, Faculty of Chemical and Food Technology, \\ Slovak University of Technology in Bratislava, Radlinského 9, 81237 Bratislava, Slovakia
}

Received: 27 July 2021

Accepted: 20 November 2021

\begin{abstract}
Repowering of industrial combined heat and power units allows reducing industrial greenhouse gases emissions. An existing industrial unit served as model in the gas turbines-based repowering study, aiming at fuel consumption and carbon dioxide emissions reduction. Following unit's model setup and verification, two conservative repowering options (hot windbox and separate gas turbine + heat recovery steam generator) were assessed from economic, energetic, and environmental point of view, including seasonal impact. Hot windbox option leads to annual power production increase by $14.3 \%$ ( $72.8 \mathrm{GWh} /$ year), accompanied by carbon dioxide emissions reduction by $3.9 \%$ ( $29.5 \mathrm{ktons} /$ year) compared to the base case. The second option delivered more significant power production increase ( +261.9 to $+298.6 \mathrm{GWh} /$ year) with $\mathrm{CO}_{2}$ emissions, either slightly higher ( $\left.+1.5 \%\right)$ or modestly lower $(-4.0 \%)$, than in base case depending on heat recovery efficiency from gas turbine exhaust. Both options show feasible economics with simple payback period as low as four years under favorable combination of fuel and electricity prices and $\mathrm{CO}_{2}$ costs. External $\mathrm{CO}_{2}$ emissions change due to the change in unit's power production further reduces the total $\mathrm{CO}_{2}$ emissions, strongly depending on the applied power production emission factor.
\end{abstract}

Keywords: cleaner power production, repowering, carbon dioxide emissions, simple payback period, industrial combined heat and power unit

\section{Introduction}

\section{Current Situation}

Reaching a substantial cut in greenhouse gases emissions (GHGs) or even carbon neutrality by 2050

*e-mail: miroslav.variny@stuba.sk

is a tremendous task for the whole mankind. Anthropogenic GHGs originate from all spheres of human activities, among which industry and transportation play a major role; with industry being responsible for around one third of the GHGs [1, 2]. Major share of industrial GHGs emissions result from the production of energies and media, mostly of electric energy and heat carriers (water steam), consumed in the production processes [3, 4]. While industrial 
needs for electric energy are largely covered by import from outer grid, steam demand is satisfied by steam production on-site in dedicated industrial combined heat and power units (CHPs) $[5,6]$.

Many existing thermal power plants (TPPs) and CHPs throughout Europe have to face their advanced age, deteriorated efficiency and the strengthening pressure to lower their carbon footprint $[7,8]$ both due to legislation [9] and growing carbon price [10, 11]. On the contrary to radical solutions such as rapid shut down of coal power plants which is associated with immense costs [12], rehabilitation and repowering of the existing units to prolong their service, increase their efficiency and decrease the pollutants emissions appears more feasible [13, 14]. Many countries that relied heavily on coal power plants, such as Russia [15], Poland [16, 17], Czechia and Slovakia [18, 19] or Balkan countries [20, 21], chose to follow this path. The power production sector and the associated renovation activities receive a lot of attention both from governments and researchers $[22,23]$. Municipal CHPs are under comparable renovation pressure due to municipal air quality, heat production costs and supply reliability and public relations $[24,25]$. Industrial CHPs largely remain out of spotlight and only a few studies on their repowering have been published recently $[26,27]$.

\section{Repowering of Thermal Power Plants and Industrial Combined Heat and Power Units}

Repowering of an existing thermal power plant (TPP) or an industrial combined heat and power unit (CHP) can be performed on various degrees of complexity, and it may require extensive investment associated with the replacement of one or several key obsolete components [28]. Reasons for repowering include the need to prolong the lifetime of an existing plant [29], which is less costly than constructing a new one, to cut down fuel costs and other operational expenses [30], and to decrease its impact on the environment [24, 31]. Often, an increase in the production capacity and plant flexibility is also pursued [32, 33]. Considering these goals, several approaches can be adopted, including:

- Fuel switch to cleaner and/or cheaper one, often retrofitting fossil fuel boiler to (co-) combustion of natural gas [34], process gases [35], biomass [36, 37] or waste fuels [38, 39];

- Refitting the existing boilers to oxycombustion [40], which requires installation of an air separation unit for oxygen-enriched air production [41, 42] improving fuel burnout, cuts down greenhouse gases emissions [43, 44], and can be a pre-requisite to carbon capture from flue gas $[45,46]$;

- Supplementing the existing boilers with a gasification unit $[47,48]$, enabling processing of a wide range of even low-quality materials into combustible gas [49, 50];

- Adding a „topping“ unit to the existing Rankine cycle unit, usually a gas turbine [51, 52], internal combustion engine [53] or a battery of fuel cells [32], resulting in multiple variants of modified plant layout [54].

Each of those variants results in layout reorganization of the remaining plant parts, usually including changes in boiler feedwater train $[55,56]$, boiler air and flue gas fans, and in flue gas and ash handling equipment [57] to boost the energy efficiency even further and to meet the tightening limits of pollutant emissions set by legislation [58]. Steam boiler retrofitting for alternative fuel as well as refitting to oxycombustion are relevant in large units, especially in thermal power plants where the effect of scale plays an important role [59, 60]. Cheap fuels of reasonable quality (such as dry biomass or waste fraction) can, however, be used in smaller boilers after a cheap retrofit or boiler replacement [6163]. However, only a retrofit coupled with topping unit installation increases the plant's capacity and improves its flexibility, both being valuable assets making this means of repowering especially interesting for industrial CHPs [64]. Among topping units, gas turbines (GTs) are of highest relevance to industrial application. Internal combustion engines are traditionally applied in municipal CHPs [65] and are less interesting for heavy industry as they release waste heat at lower temperatures than the gas turbines. Thus, repowering by GTs will be analyzed in more detail.

\section{Repowering with Gas Turbines}

Gas turbines use clean gaseous or liquid fuels combusted with significant excess of air under pressure. The resulting hot, pressurized gas is routed to an expander which drives the air compressor and generator at the same time. Depending on the gas turbine type, flue gases leave the expander at 400 to $600^{\circ} \mathrm{C}[66$, 67]. Owing to their high temperature and reasonable amount of remaining oxygen, the following options of gas turbine integration into an existing CHP can be considered:

- "Hot windbox", where exhaust gas from GT is used in the existing steam boiler as preheated combustion air or it preheats combustion air for the boiler [68, 69]. Here, a new GT is the only major equipment to be installed with a moderate increase in plant output and a slight increase in its efficiency.

- Partial steam boiler supplementing by adding a heat recovery steam generator (HRSG) downstream the GT utilizing flue gas heat content for high quality steam production [70]. Thus, the existing steam boiler operation continues at decreased load. Alternatively, a part of the boiler feedwater preheating train can be replaced by heat recovery feedwater heater [68].

- "Full repowering" with existing steam boiler replacement by a heat recovery steam generator $[71,72]$. As a result of this invasive technique, an up to $200 \%$ increase in power production can be expected accompanied by reasonable increase in plant efficiency. 
- Autonomous design with separate power production by gas and steam turbines. Steam produced in a heat recovery steam generator is injected into the GT combustion chamber and expands along with flue gas [52]. This design is very flexible and offers only a slight decrease in efficiency compared to "full repowering" [64]. On the other hand, steam is exhausted to atmosphere together with flue gas and a make-up water unit with sufficient capacity or a flue gas cooler for partial water condensation is required [73].

As discussed above, most studies analyzing repowering with GTs are applied to large power plants. A few studies deal with industrial CHPs: Ahmadi et al. [54] tested several design layouts and several suitable gas turbines for repowering of a mid-size industrial $\mathrm{CHP}$ in a petrochemical complex. Economy of scale and existing steam pressure levels enabled only for a singlepressure HRSG design. Full repowering option yielded an almost eight-fold increase in power production while maintaining the current steam supply to the customers while consumption and GHGs emissions were expected to increase 1.6 times only. Gambini et al. [74] considered various configurations of a CHP in pulp and paper industry based on steam turbines, gas turbines, combined cycles, and internal combustion engines. Considering the heat and power ratio of the plant, seasonal load dependence and multiple economic, environmental, and energetic factors evaluated by a dedicated software, the best solution for the model plant was identified. In our previous study [75], four suitable gas turbines were selected for incorporation into an existing CHP unit in a pulp and paper mill with the prospect of boosting power production, minimizing the need for power import in future and provisioning ancillary services. The existing obsolete GTs should be decommissioned, as they showed increased operational expenses, decreased efficiency, and high stack losses. An older study [76] proposed repowering the existing steam plant of a steel mill by gas turbines with multifuel option. Decrease of over $30 \%$ in steam and power production costs could be achieved with the most complex (three-pressure level) HRSG design.

\section{Aims of the Study}

Despite the documented efforts to identify optimal repowering strategies in industrial CHPs, its practical limits, effects of interactions with CHP equipment, and seasonal steam demand variability remain largely unclear. Especially significant (even multifold) increase of power production usually accompanying invasive repowering options is not a feasible solution for industrial CHPs which rather follow the fuel consumption reduction goal. Furthermore, extensive repowering often requires longer plant shutdown which, in case of an industrial power plant, is inevitably associated with production loss possibly worsening the economic parameters of the repowering project.
The presented study considers these aspects from the viewpoint of energy efficiency, environmental impact, and economic feasibility with the aim to propose a rather conservative approach to repowering. We believe this to be a viable and straightforward way to achieve both existing industrial plant renovation and efficiency improvement goal with reasonable investment. The following research procedure was designed in accordance with the aims of this study:

- Scheme of an industrial CHP based on steam and electricity cogeneration was set up and its operation and efficiency parameters were verified;

- Various gas turbine repowering options were evaluated and the best two of them were chosen for further study;

- Scheme of the industrial CHP was supplemented by individual repowering options and calculations were performed for summer and winter operation mode;

- Suitable energetic and economic indicators were calculated to compare the repowering options with base case performance;

- Carbon dioxide emissions balance was set up based on material balance of fuels combustion as well as on external emissions from power generation;

- A combined energetic-economic-environmental comparison of repowering options was performed; including further prospects of cost-efficient energy efficiency improvement.

\section{Materials and Methods}

\section{CHP Plant Model Setup}

Fig. 1 shows the flow scheme of the studied CHP before repowering. The CHP combusts heavy fuel oil (HFO) (stream No. 35) with air (stream No. 37) producing very high-pressure steam and flue gas leaving to the atmosphere at the temperature of $190^{\circ} \mathrm{C}$. Both fuel and air streams are preheated in their own heat exchangers by high-pressure steam from an extraction-condensing turbine (ECT). Fuel enters the boiler at $180^{\circ} \mathrm{C}$ and is combusted with a $30 \%$ excess of air. The considered fuel oil composition is (in mass fractions): carbon: $87 \%$, hydrogen: $12 \%$, and sulfur: $1 \%$ [77]. Relative air humidity is $65 \%$ in summer and $80 \%$ in winter. Saturated vapor pressure for water is obtained from the steam tables [78] at an average air temperature of $22^{\circ} \mathrm{C}$ in summer and of $4^{\circ} \mathrm{C}$ in winter [79]. Ambient pressure of $100 \mathrm{kPa}$ is assumed. Minimal power production of 60 MW is required. Electricity consumption of the CHP itself is typically $5 \%$ of the total electricity produced [80] comprising the consumption of process pumps, fans, and other equipment.

Feed water is preheated in a series of low temperature water heaters (LTWH), further heated in a degasser inbetween and, finally, heated in two high temperature water heaters (HTWH) to the final temperature of $210^{\circ} \mathrm{C}$. The aim of water preheating train is to increase 
the power production efficiency of thermal power plants and it is widely applied both in stationary plants [81, 82] and in steam-driven propulsion systems [83, 84]. Each water heater, as well as the degasser, is heated by steam from the turbine. To ensure sufficient heat-exchange driving force in water heaters, condensing temperature of the inlet steam is $5^{\circ} \mathrm{C}$ above the temperature of the outlet feed water. Degasser is operated at full pressure. It is assumed that the temperature of feed water increases by another $30^{\circ} \mathrm{C}$ in every heating step, so the temperature in the LTWH3 (stream No. 16) is $120^{\circ} \mathrm{C}$.

The degasser displayed in Fig. 1 has two main purposes: degassing the feed water and serving as another feed water heater mixing water with steam from the steam turbine, fuel and air pre-heating condensates, expander steam stream and condensates from HTWH. Temperature of the outlet feed water (stream No. 17) is $150^{\circ} \mathrm{C}$. Degasser exhaust (stream No. 33) represents $6 \%$ of steam supplied to the degasser.

Feed water from the degasser flows through HTWH to the boiler where it transforms from liquid to gaseous state (stream No. 1) at the temperature of $530^{\circ} \mathrm{C}$ and pressure of $9 \mathrm{MPa}$. Superheated steam expands by polytropic expansion in the ECT, where both electricity and extraction steam streams are produced. Expected polytropic efficiencies of steam expansion are summarized in Table 1 based on recent field study of MegaWatt range steam turbines [85] with seasonal variation and lower efficiency values expected in the wet steam region.

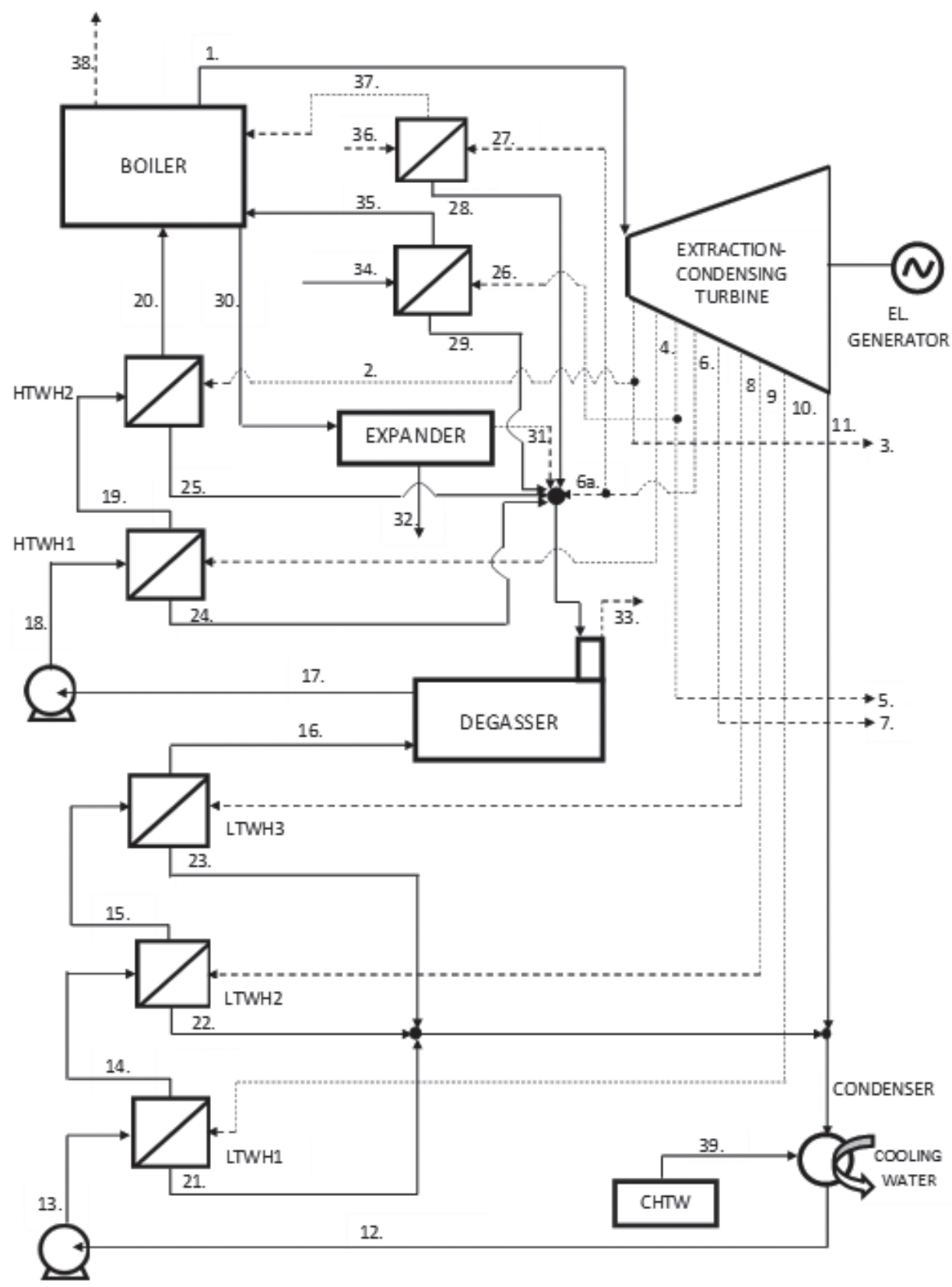

Fig. 1. Scheme of combined heat and power unit. Legend: CHTW = chemically treated water; EL. = electric energy; HTWH = high temperature water heater; $\mathrm{LTWH}=$ low temperature water heater. 
Table 1. Efficiency of polytropic steam expansion.

\begin{tabular}{|c|c|c|}
\hline Region & Winter (\%) & Summer (\%) \\
\hline Superheated steam & 85 & 80 \\
\hline Wet steam & 75 & 70 \\
\hline
\end{tabular}

Table 2. Demand for export steam.

\begin{tabular}{|c|c|c|c|}
\hline Steam & $\begin{array}{c}\text { Steam pressure } \\
(\mathrm{MPa})\end{array}$ & $\begin{array}{c}\dot{m}_{\text {winter }} \\
\left(\mathrm{t} \mathrm{h}^{-1}\right)\end{array}$ & $\begin{array}{c}\dot{m}_{\text {summer }} \\
\left(\mathrm{t} \mathrm{h}^{-1}\right)\end{array}$ \\
\hline High-pressure & 3.06 & 60 & 60 \\
\hline Intermediate-pressure & 1 & 80 & 80 \\
\hline Low-pressure & 0.4 & 130 & 30 \\
\hline
\end{tabular}

Table 3. Natural gas composition.

\begin{tabular}{|c|c|c|}
\hline Hydrocarbon & Winter & Summer \\
\hline $\mathrm{CH}_{4}$ & 0.8842 & 0.8945 \\
\hline $\mathrm{C}_{2} \mathrm{H}_{6}$ & 0.0490 & 0.0464 \\
\hline $\mathrm{C}_{3} \mathrm{H}_{8}$ & 0.0180 & 0.0194 \\
\hline $\mathrm{C}_{4} \mathrm{H}_{10}$ & 0.0488 & 0.0397 \\
\hline
\end{tabular}

The demand for export steam depends on the season. Exported stream mass flows are displayed in Table 2. In summer, the demand for export steam is lower, which results in increased mass flow of wet steam flowing to the turbine condenser to cope with the required minimum power production of $60 \mathrm{MW}$. This results in more waste heat production. In winter, the higher amount of produced low-pressure steam results in a reduction of turbine condenser load. As the ECT is designed to operate within a limited range of wet steam mass flows, $20 \mathrm{t} \mathrm{h}^{-1}$ of wet steam to the condenser is considered minimum and $100 \mathrm{t} \mathrm{h}^{-1}$ maximum. It is assumed that boiler blowdown is boiling water at $9.7 \mathrm{MPa}$, which makes up to $1.5 \%$ of the total steam output and is routed to the blowdown expander.
Stream No. 38 represents flue gas released from the boiler to the atmosphere and its temperature must be approximately by $50^{\circ} \mathrm{C}$ higher than the dew point of flue gases to prevent low temperature corrosion based on dilute sulfuric acid formation [86]. The flue gas dew point temperature is calculated based on the method by Okkes [87], employing equilibrium partial pressures of water steam, oxygen and sulfur trioxide in flue gas. A temperature of $1000^{\circ} \mathrm{C}$ is considered in the equilibrium reaction of sulfur trioxide formation (Equation (1)) for its equilibrium constant calculation. Calculated values of the dew point temperature in winter and summer are summarized in Table 3.

$$
\mathrm{SO}_{2}+0.5 \mathrm{O}_{2} \leftrightarrow \mathrm{SO}_{3}
$$

Based on the calculated temperatures of $138^{\circ} \mathrm{C}$ (winter) and $139^{\circ} \mathrm{C}$ (summer), constant temperature of $190^{\circ} \mathrm{C}$ almost independent on the season of the year was adopted for the flue gas exiting to stack.

\section{Repowering by Gas Turbine - Option No. 1}

In this repowering proposal, original CHP is supplemented by one gas turbine (GT) fired by natural gas with a power output of approximately 15-20 MW. As the rest of the plant is not affected, this repowering option represents the most conservative approach and is suitable in situations where only a small change in the plant's operation is allowed. The average composition of natural gas is defined in mass fractions with average lower calorific value in 2020 in winter for the period of October-March and in summer for the period of April-September [88] and is summed up in Table 3. Pentanes and higher hydrocarbons are considered as butane.

Assumed realistic power production efficiency of the GT is $25 \%$ with mechanical efficiency of $95 \%$, which results from available information from GT manufacturers [51]. Hot flue gas leaving the GT is used as combustion air in the boiler, where it is mixed with fresh air as shown in Fig. 2. The expected flue gas temperature at GT outlet is $500^{\circ} \mathrm{C}$. It is assumed

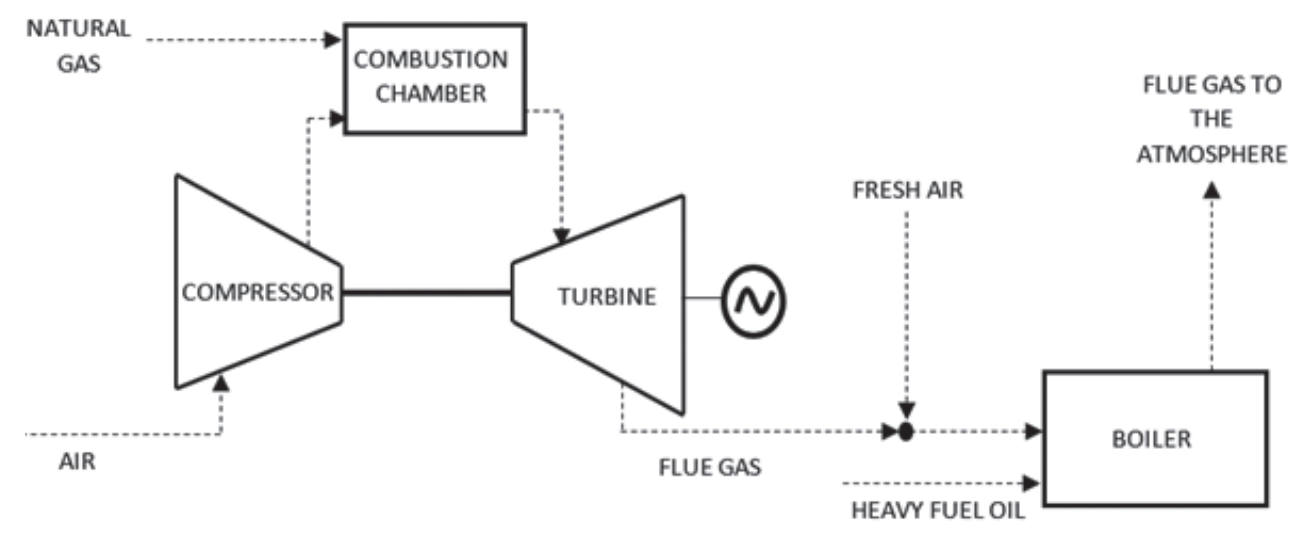

Fig. 2. Repowering scheme - option No. 1 
that flue gas from the steam boiler leaves to the atmosphere at the same temperature as before repowering. Under the given conditions, an increase in the flue gas mass flow to the stack can be expected. To maintain the existing flue gas fan and the flue gas duct without modifications, maximal allowable increase in the flue gas mass flow is set to $10 \%$.

Two different approaches were chosen for winter and summer. In winter, neither steam production nor steam turbine output is affected by repowering and an overall increase of total CHP power production is achieved. In summer, the main goal is to reduce the excessive condensing electricity production which decreases steam production while maintaining just the minimal required total CHP power output of $60 \mathrm{MW}$. Here, the heat loss in wet steam is lowered and an increase in the plant's efficiency is achieved. Own consumption of electricity by the CHP equals to $5 \%$ of its gross electricity production.

\section{Repowering by Gas Turbine - Option No. 2}

This option involves adding a GT fired by natural gas with an approximate output of $60 \mathrm{MW}$ as the second power source. Its assumed realistic power production efficiency is $30 \%$ with mechanical efficiency of $95 \%$ $[51,54]$. Flue gas leaving the combustion turbine at $500^{\circ} \mathrm{C}$ is utilized in a HRSG for superheated steam production. This repowering option is more invasive, and it affects steam production in the existing boiler as well as the steam turbine's load to a much bigger extent than option No. 1. Consequently, significant changes in the total power production, fuel consumption as well as the plant's efficiency can be expected. As in repowering option No. 1, reduction of condensing power production, e.g., fuel consumption in the existing boiler to minimum, has higher priority than total power production increase, which results in differing impact of repowering in summer and in winter.

Two different alternatives were considered. In the first alternative, a part of feed water leaving the degasser (stream No. 17) is pumped to the HRSG at the temperature of $150^{\circ} \mathrm{C}$ and leaves the $\mathrm{HRSG}$ as a superheated steam at $380^{\circ} \mathrm{C}$ and $3.06 \mathrm{MPa}$. Gas turbine and the subsequent HRSG sizing aims at fully replacing high pressure steam extraction (3.06 MPa) from steam turbine by steam production in HRSG. A reasonable pinch value of $17^{\circ} \mathrm{C}$ was adopted in the sub-100 MW HRSG design from good industrial practice and available scientific studies [69, 89]. The second one utilizes all features of the first alternative, where residual heat in flue gas after steam production in HRSG is used for additional stream No. 15 preheating, thus further lowering the stack temperature. Thereby, in addition to the first alternative, LTWH3 was set out of order and the corresponding steam bleed from the steam turbine was cancelled. Temperature profiles of hot and cold media in both alternatives are presented in Fig. 3. Scheme of the repowering option No. 2 including both alternatives can be seen in Fig. 4. Own consumption of electricity by the CHP remains 5\% of its gross electricity production in both alternatives.

\section{Mathematical Model}

The calculation procedure is based on a mathematical model of CHP consisting of material and heat balances for every unit of CHP, both for winter and summer season. The basic form of the material balance is assembled as in Equation (2), where the sum

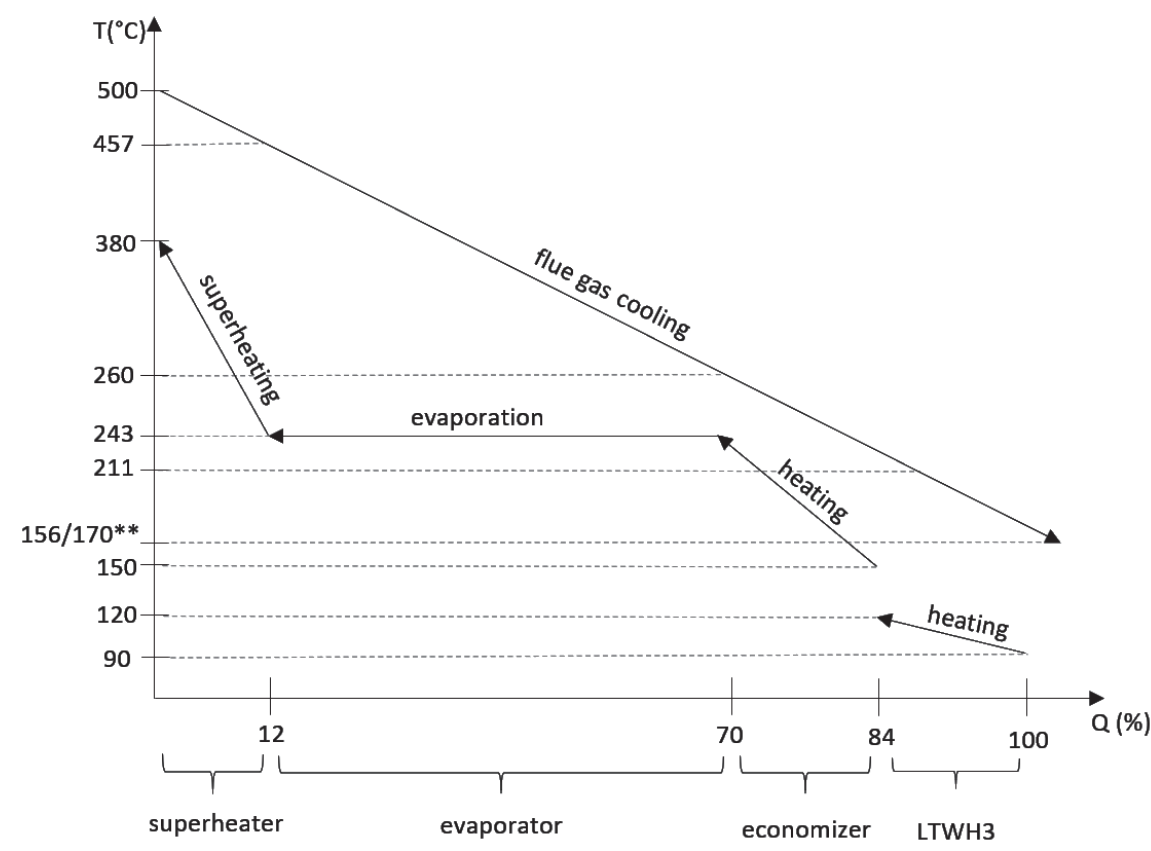

Fig. 3. T-Q diagram of HRSG, **temperature in summer. 
a)

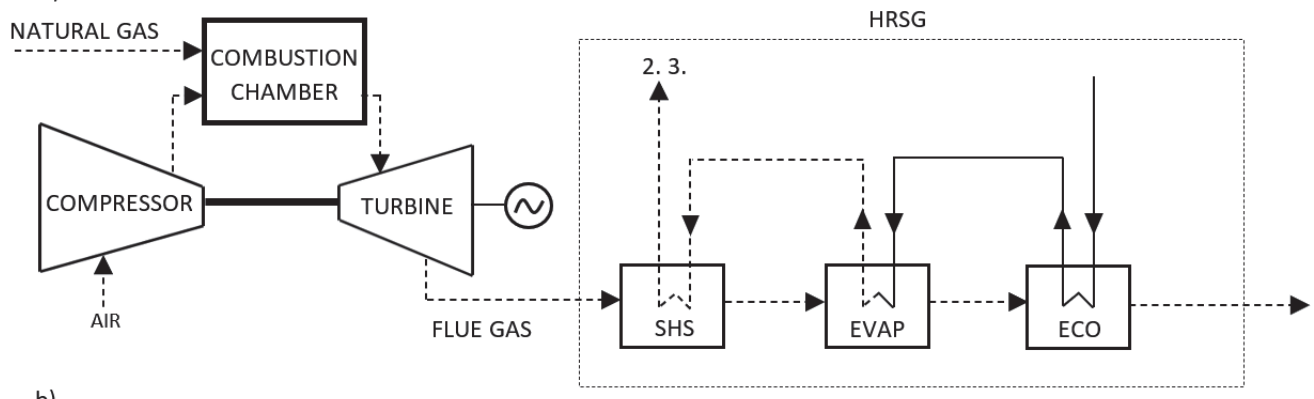

b)

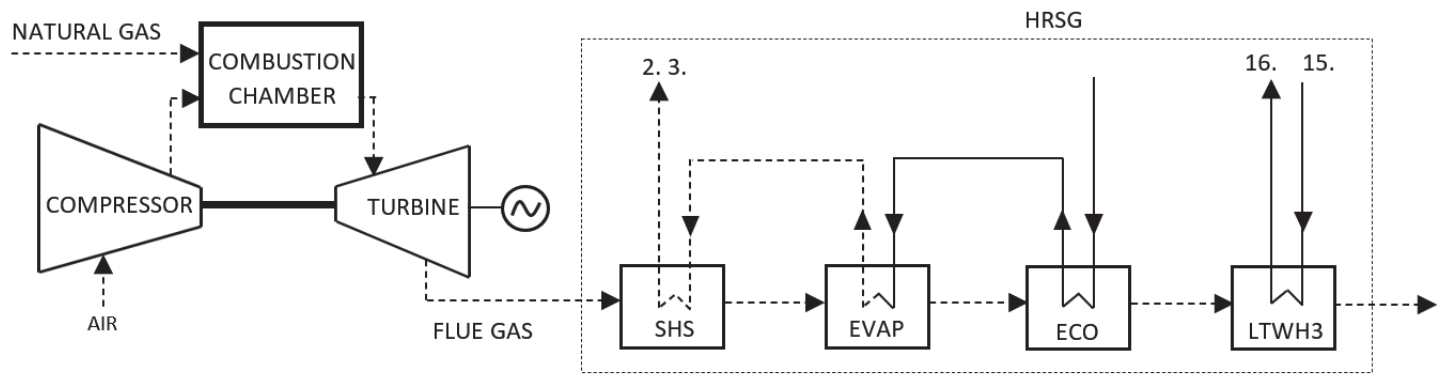

Fig. 4. Repowering scheme - option No. 2, a) first alternative, b) second alternative, legend: SHS = superheater, EVAP = evaporator, $\mathrm{ECO}=$ economizer, $\mathrm{LTWH} 3=$ low temperature water heater No. 3.

of input mass flows equals the sum of output mass flows of individual streams. In a similar way, heat balance (Equation (3)) is compiled where the sum of input heat flows equal the sum of output heat flows.

$$
\sum \dot{m}_{\text {in }}=\sum \dot{m}_{\text {out }}
$$

where $\dot{m}_{\text {in }}$ is the input mass flow, $\mathrm{t} \mathrm{h}^{-1}$, and $\dot{m}_{\text {out }}$ is the output mass flow, $\mathrm{t} \mathrm{h}^{-1}$.

$$
\sum h_{\text {in }} \dot{m}_{\text {in }}=\sum h_{\text {out }} \dot{m}_{\text {out }}
$$

where $h_{i n}$ is the enthalpy of the specific input stream, MJ $\mathrm{t}^{-1}, \dot{m}_{\text {in }}$ is the input mass flow, $\mathrm{t} \mathrm{h}^{-1}, h_{\text {out }}$ is the entalphy of the specific output stream, MJ t' ${ }^{-1}$, and $\dot{m}_{\text {out }}$ is the output mass flow, $\mathrm{t} \mathrm{h}^{-1}$. Stream enthalpies are estimated based on stream properties and composition, using physicochemical properties database including specific heat capacities of individual components [78], and online steam properties calculator [90]. Steam turbine power output, $P_{e l, S T}$, is calculated via Equation (4)

$$
P_{e l, S T}=\left(h_{\text {in }} \dot{m}_{\text {in }}-\sum h_{\text {out }} \dot{m}_{\text {out }}\right) \eta_{\text {mech }, S T}
$$

where lower indices denote inlet steam and outlet steam streams and $\eta_{\text {mech,ST }}$ stands for steam turbine's mechanical efficiency.

Inclusion of gas turbines in the model, option No. 1, starts with calculating the composition of flue gas, which is important for heat capacity and flue gas enthalpy determination, but also for boiler mass and heat balance adjustment. Using the known value of electrical and mechanical efficiency of the GT, the part of heat released by the combustion of natural gas leaving with the flue gas, Equation (5), and part of heat consumed in electricity production, Equation (6), was calculated for $1 \mathrm{~kg}$ of natural gas per hour.

$$
\dot{Q}_{e l}=\frac{\eta_{e l, G T}}{\eta_{\text {mech,GT }}} L H V_{N G} \dot{m}_{N G}
$$

where $\dot{Q}_{e l}$ is the heat flow consumed during electricity production, $\mathrm{MJ} \mathrm{h} \mathrm{h}^{-1}, \eta_{\text {mech,GT }}$ is the power production efficiency of GT, -, $\eta_{\text {mech }, S T}$ is the mechanic efficiency of GT, -, $L H V_{N G}$ is the lower heating value of natural gas, $\mathrm{MJ} \mathrm{kg} \mathrm{kg}^{-1}$, and $\dot{m}_{N G}$ is the mass flow of natural gas.

$$
\dot{Q}_{F G}=\left(1-\frac{\eta_{e l}}{\eta_{\text {mech }}}\right) Q_{L H V, N G} \dot{m}_{N G}
$$

where $Q_{F G}$ is the heat flow in the exiting flue gas, $\mathrm{MJ} \mathrm{h}^{-1}$.

In the next step, mass flow of flue gas produced per $1 \mathrm{~kg}$ of combusted natural gas is calculated using Equation (7). This calculation is not straightforward, as the flue gas composition and thus its heat capacity are not known. The calculation is performed by a series of iterations, whereby the final heat capacity of the flue gas is estimated.

$$
\dot{m}_{F G}=\frac{\dot{Q}_{F G}}{\bar{c}_{p, F G}\left(t_{F G}-t_{r e f}\right)}
$$

where $\dot{m}_{F G}$ is the mass flow of flue gas produced per $1 \mathrm{~kg}$ of natural gas, $\mathrm{kg} \mathrm{h}^{-1}, \dot{Q}_{F G}$ is the heat flow 
in the exiting flue gas, $\mathrm{MJ} \mathrm{h}^{-1}, \bar{c}_{p, F G}$ is the average specific isobaric heat capacity of flue gas, $t_{F G}$ is the temperature of flue gas, and $t_{r e f}$ is the reference temperature of $0^{\circ} \mathrm{C}$.

Excess air for heavy fuel oil combustion in the original boiler remains unchanged, allowing for calculation of the material balance of heavy fuel combustion with flue gas from GT mixed as combustion air with fresh air for $1 \mathrm{~kg}$ per hour of flue gas. The next step is divided into two parts, for winter and summer season. In winter, mass and heat balances for every unit of CHP except for the original boiler remain unchanged and only iterations for the overall mass balance of heavy fuel oil combustion are performed. In summer, reduction of the condensing power production is desired, so the amount of steam produced in the boiler is reduced. Therefore, a series of iterations both for overall material balance of heavy fuel combustion and for the individual units in CHP are performed. The last step is to calculate the actual amount of natural gas consumed in the GT combustion chamber and the actual overall material balance of natural gas combustion. Power produced by the gas turbine, $P_{e l, S T}$, is calculated via Equation (8):

$$
P_{e l, G T}=L H V_{N G} \dot{m}_{N G} \eta_{e l, G T}
$$

First and second steps of repowering option No. 2 calculation procedure are identical with those of option No. 1, applying Equations (4), (5) and (6). After completing the first two steps, the overall material balance of natural gas combustion for $1 \mathrm{~kg}$ of combusted natural gas is calculated.

Equations of material and enthalpy balances for LTWH1, LTWH2, LTWH3 (for the first alternative), HTWH1, HTWH2, blowdown expander, condenser, fuel oil preheating and air remain valid. The addition of a HRSG increases the mass flow of the blowdown to the expander, as well as that of saturated steam flowing from the expander to the degasser. Therefore, steam mass flow from the condensing turbine (stream No. 6a) to the degasser decreases. Since a part of the feed water from the degasser goes to the flue gas boiler (Equation (9)), less heat needs to be transferred in HTWH1 and HTWH2, as also the mass flow of high-pressure steam to HTWH1 (stream No. 4) is lower.

$$
\dot{m}_{17}=\dot{m}_{\text {toHRSG }}+\dot{m}_{\text {toHTWH }}
$$

where $\dot{m}_{17}$ is the mass flow of feed water from the degasser, $\dot{m}_{\text {toHRSG }}$ is the part of the feed water pumped to HRSG, and $\dot{m}_{\text {toHTWH }}$ is the feed water mass flow into HTWH1 and HTWH2.

As a result, the demand for superheated steam production in the original boiler decreases as well as the amount of feed water from HTWH2, which again affects the amount of transferred heat and the mass flow of high-pressure steam. Calculation of material and heat balances of individual CHP units is therefore iterative.
When the mass flow of feed water to the HRSG is known, the amount of heat received by the feed water in the HRSG can be obtained. Subsequently, flue gas mass flow required to heat, evaporate and overheat the feed water to the required state of $3.06 \mathrm{MPa}$ and $380^{\circ} \mathrm{C}$ can be calculated. Based on the actual flue gas mass flow, the last step is to calculate the actual overall material balance of natural gas combustion. Finally, net power output of the CHP in any of the considered options, i, (base case without repowering, repowering option No. 1, repowering option No. 2), $P_{e l, C H P, i}$, is calculated using Equation (10) where 0.95 includes the assumed internal power consumption of $5 \%$.

$$
P_{e l, C H P, i}=0.95\left(P_{e l, S T, i}+P_{e l, G T, i}\right)
$$

\section{Process Economics and Investment Cost Estimation}

When choosing the most suitable repowering proposal, calculation of the initial investment and payback period is a crucial step. First, the price of GT and HRSG is calculated. The cost of the gas turbine is calculated using Equations (11) and (12) [91], cost of the HRSG is calculated based on Equation (13) [92].

$$
\begin{aligned}
& y=877.58 x^{-0.2305} \\
& C_{G T, 2008}=1000 y x
\end{aligned}
$$

where $\mathrm{y}$ is the price of GT in 2008, USD $\mathrm{kW}^{-1}, \mathrm{x}$ is the net GT output, MW, and $C_{G T, 2008}$ is the price of GT in 2008, USD.

$$
\begin{gathered}
C_{H R S G, 1996}=C_{41}\left[\left(\frac{\dot{Q}_{S H}}{\Delta T_{l s, S H}}\right)^{0.8}+\left(\frac{\dot{Q}_{\text {evap }}}{\Delta T_{l s, \text { vap }}}\right)^{0.8}\right. \\
\left.+\left(\frac{\dot{Q}_{\text {eco }}}{\Delta T_{l s, \text { eco }}}\right)^{0.8}+\left(\frac{\dot{Q}_{L T W H 3}}{\Delta T_{l s, L T W H 3}}\right)^{0.8}\right] \\
+C_{42} \dot{m}_{\text {toHRSG }}+C_{43} \dot{m}_{\text {fluegas }}^{1.2}
\end{gathered}
$$

where $C_{H R S G, 1996}$ is the price of HRSG in 1996, USD, $\Delta T_{l s}$ is the logarithmic mean of temperatures in the individual parts of the HRSG, $\mathrm{K}, C_{41}-C_{43}$ are coefficients given in Table $4, \dot{Q}_{S H}$ is the heat flow in superheater, $\mathrm{kW}, \dot{Q}_{\text {evap }}$ is the heat flow in vaporizer, $\mathrm{kW}, \dot{Q}_{\text {есо }}$ is the heat flow in economizer, $\mathrm{kW}, \dot{Q}_{L T W H 3}$ is the heat flow in the part of HRSG substituting LTWH3, kW, $\dot{m}_{\text {toHRSG }}$ is the mass flow of feed water flowing to HRSG, $\mathrm{kg} \mathrm{s}^{-1}$, and $\dot{m}_{\text {flugas }}$ is the mass flow of flue gas from $\mathrm{GT}, \mathrm{kg} \mathrm{s}^{-1}$.

In the next step, USD are converted to EUR based on the current exchange rate of $100 \mathrm{USD}=82.88 \mathrm{EUR}$ [93]. Subsequently, the price is recalculated using the CEPCI (Chemical Engineering Plant Cost Index) index to the current price based on Equations (14) and (15) using the latest available data for 2019 [94] 
Table 4. Coefficients for calculating the HRSG investment costs (Equation (13)).

\begin{tabular}{|c|c|}
\hline Coefficient & Value \\
\hline$C_{41}\left(U S D \mathrm{~kW}^{-0.8} \mathrm{~K}^{0.8}\right)$ & 6570 \\
\hline$C_{42}\left(U S D \mathrm{~kg}^{-1} s\right)$ & 21276 \\
\hline$C_{43}\left(U S D \mathrm{~kg}^{-1.2} S^{1.2}\right)$ & 1184.4 \\
\hline
\end{tabular}

Table 5. CEPCI index values.

\begin{tabular}{|c|c|}
\hline Year & CEPCI index (-) \\
\hline 1996 & 382 \\
\hline 2008 & 575 \\
\hline 2019 & 607.5 \\
\hline
\end{tabular}

and values for years 1996 and 2008. CEPCI index values are displayed in Table 5. Such price recalculation considers the development of equipment cost, labor cost and other factors that impact the final price estimate and is a common way to make the price estimate more accurate [95].

$$
C_{G T, 2019}=\frac{C E P C I_{2019}}{C E P C I_{2008}} C_{G T, 2008}
$$

where $C_{G T, 2019}$ is the cost of GT in 2019, EUR, $C E P C I_{2019}$ is the index value in 2019, -, CEPCI ${ }_{2008}$ is the index value in 2008, -, and $C^{2} E P C I_{2008}$ is the cost of GT in 2008, EUR.

$$
C_{H R S G, 2019}=\frac{C E P C I_{2019}}{C E P C I_{1996}} C_{H R S G, 1996}
$$

where $C_{H R S G, 2019}$ is the cost of HRSG in 2019, EUR, $C E P C_{2019}$ is the index value in $2019,-, C E P C I_{1996}$ is the index value in 1996, -, and $C_{H R S G, 2019}$ is the cost of HRSG in 1996, EUR.

Not only the cost of the main equipment is important but also cost related to the preparation of the site, installation of new pipelines, metering and regulation equipment, financial reserves for unforeseen events and other factors play role in the final investment cost estimation. The overall investment cost of repowering is calculated based on Equation (16) using Lang's factors listed in [95] adjusted according to the CHP requirements displayed in Table 6.

$$
\begin{aligned}
& C_{\text {repowering }}=\left(1+f_{P I P}\right) C_{2019}+\left(f_{E R}+f_{I N S T}\right. \\
& \left.+f_{E L E C}+f_{S P}+f_{D E C}+f_{C O N T}+f_{W C}\right) C_{2019}
\end{aligned}
$$

where the lower indices represent the following: PIP - piping, ER - erection, INST - installation, ELEC - electric equipment installation and wiring, SP - site preparation, DEC - direct engineering costs,
Table 6. Adjusted Lang's factors.

\begin{tabular}{|c|c|}
\hline Factor categorization & Factor (-) \\
\hline$f_{E R}-$ equipment erection & 0.4 \\
\hline$f_{P I P}-$ piping & 0.35 \\
\hline$f_{I N S T}-$ instrumentation & 0.2 \\
\hline$f_{E L E C}-$ electrical & 0.1 \\
\hline$f_{S P}-$ site preparation & 0.1 \\
\hline$f_{D E C}-$ design and engineering & 0.5 \\
\hline$f_{C O N T}-$ contingency & 0.2 \\
\hline$f_{W C}-$ working capital & 0.3 \\
\hline
\end{tabular}

CONT - contingency, WC - working capital. Simple payback period (SPBP), Equation (17), is determined for each repowering alternative, i, as the share of investment cost estimated by Equation (16) and sum of differential cash flows, summed over $\mathrm{j}$ working hours per year. Differential cashflow, Equation (18), is the difference between (income from net produced electricity minus fuel costs) before and after the repowering. Annual working time assumed is 8600 hours, with summer and winter regime deemed to last 3400 hours each.

$$
\begin{gathered}
\operatorname{SPBP}_{i}=\frac{C_{\text {repowering }, i}}{\sum_{j} \text { Cashflow }, i, j} \\
\text { Cash flow } i=\Delta \dot{m}_{35, i} \cdot C_{35}+\Delta \dot{m}_{N G, i} \cdot C_{N G} \\
+\Delta \dot{m}_{\mathrm{CO}_{2, \mathrm{CHP}, i} \cdot C_{\mathrm{CO}_{2}}+\Delta P_{e l, C H P i} \cdot C_{e l}}
\end{gathered}
$$

where $\dot{m}_{35}$ is the mass flow of used heavy fuel oil (stream No. 35), $\mathrm{t} \mathrm{h}^{-1}, C_{35}$ is the price of heavy fuel oil, $€ \mathrm{t}^{-1}, \dot{m}_{N G}$ is the mass flow of used natural gas, $\mathrm{t} \mathrm{h}^{-1}, C_{N G}$ is the price of natural gas, $€ \mathrm{t}^{-1}, \dot{m}_{\mathrm{CO}_{2}, \mathrm{CHP}}$ is the mass flow of produced carbon dioxide in $\mathrm{CHP}, \mathrm{t} \mathrm{h}^{-1}, \mathrm{C}_{\mathrm{CO}_{2}}$ is the price of carbon dioxide, $€ \mathrm{t}^{-1}, P_{e l, C H P}$ is the net electric output of CHP, MW, and $C_{e l}$ is the price of electricity, $€ \mathrm{MWh}^{-1}$.

Based on market prices monitoring, it is obvious that prices mentioned in Equation (18) are not stable and change due to various macro- and microeconomic factors. Natural gas price varied a lot in past years, mostly between 150 and $450 € \mathrm{t}^{-1}$ [96] but, as for input for economic analysis, following price relation to heavy fuel oil price in $€ \mathrm{GJ}^{-1}$ is assumed: $0.9: 1 ; 1: 1 ; 1.1: 1$. Therefore, a range of those prices is chosen for sensitivity analysis following the actual prognosis of price developments summarized in Table 7 with the help of data from [97-99].

\section{Energetic and Environmental Evaluation}

Growing interest in more efficient use of thermal energy is supported as greenhouse emissions are 
Table 7. Price intervals of inputs and outputs considered in economic analysis. el = electric energy, $\mathrm{HFO}=$ heavy fuel oil .

\begin{tabular}{|c|c|c|}
\hline Item & Price $(€)$ & Reference \\
\hline$C_{\mathrm{HFO}}$ & 150 to 350 & {$[97]$} \\
\hline$C_{\mathrm{CO}_{2}}$ & 30 to 50 & {$[98]$} \\
\hline$C_{e l}$ & 40 to 70 & {$[99]$} \\
\hline
\end{tabular}

produced during fuel combustion and carbon price has risen rapidly in the last few years. When considering the most suitable repowering proposal, the amount of carbon dioxide released in the flue gas to the atmosphere in situ (in CHP) is an important factor calculated from the flue gas flow and composition using Equation (19). In case of repowering option No. 2, $\mathrm{CO}_{2}$ in flue gas both from boiler and GT is summed up separately in Equation (20).

$$
\dot{m}_{\mathrm{CO}_{2}, \mathrm{CHP}}=\dot{m}_{38} w_{38, \mathrm{CO}_{2}}
$$

where $\dot{m}_{\mathrm{CO}_{2} \text { CHP }}$ is the mass flow of carbon dioxide emitted in CHP, $\mathrm{t} \mathrm{h}^{-1}, \dot{m}_{38}$, is the mass flow of flue gas, $\mathrm{t} \mathrm{h}^{-1}$, and $\dot{m}_{38, \mathrm{CO}_{2}}$ is the mass fraction of carbon dioxide, - .

$$
\dot{m}_{\mathrm{CO}_{2}, \mathrm{CHP}}=\dot{m}_{38} w_{38, \mathrm{CO}_{2}}+\dot{m}_{\text {fluegas }} w_{\text {fluegas }, \mathrm{CO}_{2}}
$$

where $\dot{m}_{\text {fluegas }}$ is the mass flow of flue gas from GT, $\mathrm{t} \mathrm{h}^{-1}$, and $w_{\text {fluegas } \mathrm{CO}_{2}}$ is the mass fraction of carbon dioxide in flue gas from GT, -

A change in an industrial CHP performance will inevitably affect its surroundings. As it supplies heat and power to the industrial production units, any change in power production, at the same heat delivery, will cause transmission system imbalance and induce a change in power production with an opposite sign elsewhere. To quantify the environmental impact of such an action, power production emission factors are used [14, 100], expressing the released carbon dioxide emissions (or emissions of several important greenhouse gases recalculated to $\mathrm{CO}_{2}$ equivalent) per unit of produced electricity [101]. While this concept is clear, there is a lively debate on its proper application to find a unified approach to this emission factor estimation [102]. Several researchers use a single average country-related value while others incorporate power import and export and yet others recommend using marginal factors [103] that might vary seasonally as well as during a single day depending on the actual balance of the grid [104]. Moreover, with increasing use of renewables in the electric energy production sector [105], the corresponding emission factor values are likely to decrease in future, which should also be considered [106, 107]. Therefore, it makes little sense to use a single emission factor value and two distinctive scenarios were set up: one adopting the emission factor of Slovenské elektrárne, a.s., adopted from our previous study [108]; and the other one the emission factor of a conventional coal power plant [109]. Thus, a more realistic assessment of possible carbon dioxide balance changes resulting from repowering is targeted. Overall carbon dioxide balance incorporating the external power production effect is assessed by Equation (21) with EF denoting the applied emission factor. This equation allows comparing carbon footprint of individual repowering options with the base case.

$$
\dot{m}_{\mathrm{CO}_{2}, \mathrm{tot}, i}=\dot{m}_{\mathrm{CO}_{2}, \mathrm{CHP}, i}-P_{e l, C H P, i} E F
$$

Energetic indicators chosen to document the repowering impact on CHP operation are: net electric efficiency, Equation (22); and cogeneration efficiency, Equation (23).

$$
\eta_{e l, i}=\frac{P_{e l, C H P, i}}{\dot{Q}_{c o m b, i}}
$$

where $\eta_{e l}$ is the electric efficiency of CHP, -, $P_{e l, C H P, i}$ is the net electric output of CHP, MW, and $\stackrel{\text { el.,CHP, },}{Q_{\text {comb }, i}}$ is the heat flow released by fuel combustion, MW.

$$
\eta_{c o g, i}=\frac{\dot{Q}_{\text {export }}-\dot{Q}_{C H T W}+P_{e l, C H P, i}}{\dot{Q}_{c o m b, i}}
$$

where $\eta_{c o g}$ is the cogeneration efficiency of CHP, -, $\dot{Q}_{\text {export }}$ is the heat export, $\mathrm{MW}, \dot{Q}_{C H T W}$ is the heat flow of chemically treated water, $\mathrm{MW}, P_{e l, E C T}$ is the electric output of ECT, MW, $P_{e l, G T}$ is the electric output of GT, $\mathrm{MW}$, and $Q_{\text {comb }}$ is the heat flow produced in the process of natural gas combustion, MW, defined by Equation (24).

$$
\dot{Q}_{c o m b, i}=\dot{m}_{35, i} \cdot L H V_{35}+\dot{m}_{N G, i} \cdot L H V_{N G}
$$

where $\dot{m}_{35}$ is the mass flow of combusted heavy fuel oil, $\mathrm{t} \mathrm{s}^{-1}, L H V_{35}$ is its lower heating value, $\mathrm{MJ} \mathrm{t} \mathrm{t}^{-1}, \dot{m}_{N G}$ is the mass flow of combusted natural gas, $\mathrm{t} \mathrm{s}^{-1}$, and $L H V_{N G}$ is its lower heating value, $\mathrm{MJ} \mathrm{t}^{-1}$. Heat export is calculated by Equation (25) and heat import associated with cold chemically treated water is defined by Equation (26).

$$
\dot{Q}_{\text {export }}=\dot{m}_{3} \cdot \bar{h}_{3}+\dot{m}_{5} \cdot \bar{h}_{5}+\dot{m}_{7} \cdot \bar{h}_{7}
$$

where $\dot{Q}_{\text {export }}$ is the heat export, $\mathrm{MW}, \dot{m}_{3}$ is the mass flow of low-pressure export steam (stream No. 3), $\mathrm{t} \mathrm{s}^{-1}, \bar{h}_{3}$ is the specific enthalpy of low-pressure export steam (stream No. 3), MJ t ${ }^{-1}, \dot{m}_{5}$ is the mass flow of intermediate-pressure export steam (stream No. 5), $\mathrm{t} \mathrm{s}^{-1}, \overline{h_{5}}$ is the specific enthalpy of intermediate-pressure export steam (stream No. 5 ), $\mathrm{MJ} \mathrm{t}^{-1}, \dot{m}_{7}$ is the mass flow of high-pressure export steam (stream No. 7), $\mathrm{t} \mathrm{s}^{-1}$, and $\bar{h}_{7}$ is the specific enthalpy of high-pressure export steam (stream No. 7), $\mathrm{MJ} \mathrm{t}^{-1}$. 
Table 8. Performance indicators of CHP before repowering.

\begin{tabular}{|c|c|c|}
\hline Performance indicator & Winter & Summer \\
\hline$\dot{m}_{1}\left(t h^{-1}\right)$ & 453.71 & 395.24 \\
\hline$\dot{m}_{11}\left(t h^{-1}\right)$ & 20.00 & 87.25 \\
\hline$\dot{m}_{35}\left(t h^{-1}\right)$ & 29.05 & 25.27 \\
\hline$\dot{m}_{N G}\left(t h^{-1}\right)$ & 0 & 0 \\
\hline$\dot{m}_{38}\left(t h^{-1}\right)$ & 562.66 & 492.70 \\
\hline$P_{\text {el.CHP }}(M W, n e t)$ & 61.07 & 57.00 \\
\hline
\end{tabular}

$$
\dot{Q}_{C H T W}=\dot{m}_{39} \cdot \bar{h}_{39}
$$

where $\dot{Q}_{\text {СНTW }}$ is the heat flow imported in cold $\left(20^{\circ} \mathrm{C}\right)$ chemically treated water, $\mathrm{MW}, \dot{m}_{39}$ is the mass flow of chemically treated water (stream No. 39), $\mathrm{t} \mathrm{s}^{-1}$, and $\bar{h}_{39}$ is the specific enthalpy of chemically treated water (stream No. 39), $\mathrm{MJ} \mathrm{t}^{-1}$.

\section{Results and Discussion}

\section{Basic CHP Model Verification}

Basic CHP model results are summed up in Table 8. As it can be seen, season of the year affects the CHP operation significantly. Higher steam export in winter coupled with increased backpressure electric energy cogeneration allows for a significant reduction of condensing power production. Mass flow of steam exhaust to condenser (stream No. 11) reached

Table 9. Performance indicators of repowered CHP - option No. 1.

\begin{tabular}{|c|c|c|}
\hline Performance indicator & Winter & Summer \\
\hline$\dot{m}_{1}\left(t h^{-1}\right)$ & 453.71 & 332.55 \\
\hline$\dot{m}_{11}\left(t h^{-1}\right)$ & 20.00 & 46.68 \\
\hline$\dot{m}_{35}\left(t h^{-1}\right)$ & 26.18 & 19.43 \\
\hline$\dot{m}_{N G}\left(t h^{-1}\right)$ & 4.40 & 3.33 \\
\hline$\dot{m}_{38}\left(t h^{-1}\right)$ & 586.43 & 439.27 \\
\hline
\end{tabular}

a pre-set minimum of $20 \mathrm{t} \mathrm{h}^{-1}$ in winter, whereas in summer it had to reach over $85 \mathrm{t} \mathrm{h}^{-1}$ to secure the minimum CHP gross power production of $60 \mathrm{MW}$. Net power production in winter was slightly over $61 \mathrm{MW}$ despite minimized condensing power production. The difference in steam production in boiler (stream No. 1) between summer and winter was somewhat less than $60 \mathrm{t} \mathrm{h}^{-1}$ mirroring the trends in steam export and condensing power production, translated into fuel consumption difference (stream No. 11) of around $4 \mathrm{t} \mathrm{h}^{-1}$. These results agree well with the operation of a real industrial CHP where steam production in winter is around 450 to $600 \mathrm{t} \mathrm{h}^{-1}$, and gross power production is 60 to $85 \mathrm{MW}$, mostly depending on actual ambient temperature and thus on low-pressure steam demand, as this steam is utilized mostly for heating purposes. Steam production drops below $400 \mathrm{t} \mathrm{h}^{-1}$ in summer and low-pressure steam export is close to zero.

As to obtain yet more data for model verification, a model for condensing power production only was set-up and presented elsewhere [110]. Specific steam production for condensing power production of over $4.5 \mathrm{t} \mathrm{MWh}^{-1}$ and net electric efficiency of $30.6 \%$ are within the range of performance parameters of subcritical sub-100 MW scale thermal power plants listed in reference literature $[68,80]$. Similarly, Ahmadi et al. [27] presented data from an existing condensing steam turbine consuming $9.4 \mathrm{~kg} \mathrm{~s}^{-1}$ of steam and producing $8 \mathrm{MW}$ of electricity, yielding specific steam consumption of $4.2 \mathrm{t} \mathrm{MWh}^{-1}$. It can be concluded that the presented CHP model realistically describes real industrial CHP operation and can be used as a base for calculation of repowering options.

\section{Repowering Results: Energetic and Environmental Evaluation}

Basic operation parameters of individual repowering options are provided in Table 9 and Table 10. More detailed energetic and environmental evaluation of both basic CHP before repowering and of individual repowering options is shown in Table 11 to Table 13.

As can be recognized from Table 9 and Table 10, CHP operation after repowering is modified in terms of fuel consumption, steam production and condensing power production as well. All repowering options reduce steam boiler load and HFO consumption.

Table 10. Performance indicators of repowered CHP - option No. 2. alt $=$ alternative.

\begin{tabular}{|c|c|c|c|c|}
\hline Performance indicator & Winter (alt. 1) & Winter (alt. 2) & Summer (alt. 1) & Summer (alt. 2) \\
\hline$\dot{m}_{1}\left(t h^{-1}\right)$ & 342.62 & 318.13 & 197.56 & 182.10 \\
\hline$\dot{m}_{11}\left(t h^{-1}\right)$ & 20.00 & 20.00 & 20.00 & 20.00 \\
\hline$\dot{m}_{35}\left(t h^{-1}\right)$ & 22.17 & 20.59 & 12.78 & 11.78 \\
\hline$\dot{m}_{N G}\left(t h^{-1}\right)$ & 12.67 & 12.37 & 10.76 & 10.58 \\
\hline$\dot{m}_{38}\left(t h^{-1}\right)$ & 429.52 & 398.83 & 249.21 & 229.72 \\
\hline
\end{tabular}


Table 11. Energetic and environmental evaluation of CHP before repowering.

\begin{tabular}{|c|c|c|}
\hline Performance indicator & Winter & Summer \\
\hline$\dot{m}_{\mathrm{CO}_{2}}\left(t h^{-1}\right)$ & 92.60 & 81.09 \\
\hline$P_{e l, C H P}(M W$, gross $)$ & 64.28 & 60.00 \\
\hline$P_{e l, C H P}(M W, n e t)$ & 61.07 & 57.00 \\
\hline$\eta_{e l}(\%)$ & 19.59 & 21.01 \\
\hline$\eta_{c o g}(\%)$ & 85.83 & 70.01 \\
\hline
\end{tabular}

Condensing power production (see stream No. 11 $=$ exhaust steam to steam condenser) in winter is strongly reduced in repowering option 1, while in repowering option 2 it is minimized. Decrease of HFO consumption is almost counterbalanced by natural gas consumption in gas turbines, which is analyzed in more detail below. Option 2, alternative 2 can be termed as more efficient compared to option 2, alternative 1 , regarding fuel consumption and steam production. In option 2, alternative 2 in summer steam boiler load reaches around $40 \%$ of that before repowering in winter. Operation range of 40 to $100 \%$ of nominal steam production can be maintained in reality as well, without any visible loss in boiler thermal efficiency, while a further reduction of boiler load should be considered with caution.

More details of CHP operation before repowering are provided in Table 11. Carbon dioxide production amounts to over 80 to $90 \mathrm{t} \mathrm{h}^{-1}$ depending on the season of the year. The achieved power production efficiency is only modest, around $20 \%$, which corresponds with a significant share of backpressure electricity. However, cogeneration efficiency exceeds $85 \%$ in winter and reaches $70 \%$ in summer, indicating an efficient CHP operation especially in winter. Summer cogeneration efficiency drop of over $15 \%$ leads to power production efficiency increase by less than $2 \%$, clearly stressing the inefficiency of condensing power production.

Table 12 indicates that power production increase of over $16 \mathrm{MW}$ in summer and a zero power production change in winter when comparing CHP operation before repowering and repowering option 1 . This again stresses the need to assess the CHP operation on a seasonal basis. Winter operation of the CHP and, more specifically of the steam turbine, does not allow for a reduction of condensing power production as it is already minimal before repowering. Thus, steam production in boiler is the same as before repowering and there is an overall increase in fuel consumption, translated into power production increase. On the other hand, power production by the gas turbine in summer is counterbalanced by decreased condensing power production in the steam turbine, leading to an unchanged total power production and a significant decrease in overall fuel consumption. This translates into the values of power production efficiency, where
Table 12. Energetic and environmental evaluation of repowered CHP - option no. 1.

\begin{tabular}{|c|c|c|}
\hline Performance indicator & Winter & Summer \\
\hline$\dot{m}_{\mathrm{CO}_{2}}\left(t h^{-1}\right)$ & 95.65 & 71.18 \\
\hline$P_{e l, C H P}(M W$, gross $)$ & 61.07 & 44.09 \\
\hline$P_{e l, C H P}(M W, n e t)$ & 16.94 & 12.91 \\
\hline$\eta_{e l}(\%)$ & 23.12 & 27.79 \\
\hline$\eta_{c o g}(\%)$ & 84.32 & 80.68 \\
\hline
\end{tabular}

a modest increase from 19.6 to over $23 \%$ can be seen in winter but a far more visible increase from 21 to almost $28 \%$ is documented in summer. The above facts are reflected in carbon dioxide production as well: while it is slightly increased in winter, compared to the situation before repowering, it is visibly reduced in summer, due to condensing power production decrease. Compared with the situation before repowering cogeneration efficiency improves a lot in summer but is slightly lower in winter. Yilmazoğlu and Durmaz [68] tested hot windbox repowering on an existing ageing sub-100 MW coal power plant with the finding that the achievable power production increase is between 10 and $22 \%$. This is in line with our finding as the annual power production in this repowering option increases by $14 \%$.

Similar features can be recognized in repowering option 2, as documented in Table 13. However, the gas turbine output in this option is far bigger than that in option 1 , meaning that even condensing power production reduction to minimum in summer and the associated drop in steam turbine output cannot counterbalance it. Thus, net power production increase is seen both in summer and in winter, regardless of alternative 1 or 2 . This further amplifies the change in carbon dioxide production - a decent increase in winter and a visible decrease in summer can be observed in Table 13. Option 2, alternative 2 yields lower carbon dioxide production than alternative 1 , due to improved heat recuperation from flue gas, as documented both in Fig. 3 and Table 10. The achieved power production efficiency is almost constant, around $28 \%$, with only a slight influence of both season of the year and alternative. Ahmadi et al. [54] arrived at power production efficiencies of over $37 \%$ with full repowered design in a sub-100 MW industrial plant, but their design counted with selling a great deal of generated power to the external grid; both factors leading to a more efficient repowered plant operation than in this study where exporting power to external grid is not considered. Modesto and Nebra [76] achieved power production efficiency of almost 50\% with full repowering industrial CHP design converted into a $300 \mathrm{MW}$-scale combined cycle power plant.

Cogeneration efficiency values are higher for alternative 2 than for alternative 1 but for both alternatives these values are somewhat lower than 
Table 13. Energetic and environmental evaluation of repowered CHP - option no. 2.

\begin{tabular}{|c|c|c|c|c|}
\hline Performance indicator & Winter (alt. 1) & Winter (alt. 2) & Summer (alt. 1) & Summer (alt. 2) \\
\hline$\dot{m}_{C \mathrm{C}_{2}}\left(t h^{-1}\right)$ & 105.80 & 99.92 & 70.57 & 66.87 \\
\hline$P_{e l, C H P}(M W$, gross $)$ & 52.87 & 48.92 & 29.12 & 26.78 \\
\hline$P_{e l, C H P}(M W$, net $)$ & 56.88 & 55.55 & 48.63 & 47.80 \\
\hline$\eta_{e l}(\%)$ & 27.40 & 27.51 & 28.15 & 28.35 \\
\hline$\eta_{c o g}(\%)$ & 78.97 & 81.90 & 76.34 & 78.94 \\
\hline
\end{tabular}

before repowering in winter and higher than that in summer. Their decrease in winter can be attributed to a modest stack loss increase, associated with overall flue gas production increase.

Table 14 provides detailed calculation of annual carbon dioxide balance, incorporating the contribution of external power production. Taking only the CHP into account, there is a small $\mathrm{CO}_{2}$ production decrease associated with repowering option 1 and repowering option 2, alternative 2. On the other hand, $\mathrm{CO}_{2}$ production is increased slightly in option 2, alternative 1 . Power production change is more visible, amounting to almost $73 \mathrm{GWh}$ year ${ }^{-1}$ in option 1 and to almost $300 \mathrm{GWh}$ year $^{-1}$ in option 2, alternative 1. This leads to a cut in carbon dioxide emissions elsewhere which is quantified using two distinctive emission factors as indicated in Tab. 14. With the first one, reflecting the average of Slovakia's major power producer, Slovenské elektrárne a.s., the overall $\mathrm{CO}_{2}$ balance changes only modestly, but enough to see that all repowering options yield a cut in overall $\mathrm{CO}_{2}$ emissions. The second one, corresponding to a coal power plant, yields much bigger changes, leading to a most significant cut in overall $\mathrm{CO}_{2}$ emissions associated with repowering option 2, alternative 1 . On the contrary to that, it yielded $\mathrm{CO}_{2}$ production increase, considering the CHP only. This further documents the need to evaluate the environmental impact of repowering activities very carefully and to consider more evaluation alternatives whenever possible, which is in line with recommendations formulated in [102].

\section{Repowering Results: Economic Evaluation and Sensitivity Analysis}

Total investment cost (in mil. $€$ ) estimates for individual repowering options are: option 1: 22.4; option 2, alternative 1: 62.9; option 2, alternative 2: 63.1. Almost identical values for both alternatives result from counteracting effects of gas turbine and heat recovery steam generator costs. Economic analysis in form of simple payback period calculation for various combinations of energies and media costs is provided in Figs 5-9.

Fig. 5 presents results for basic dataset of prices. Quite favorable payback periods are observed for option 1 and option 2, alternative 2. There is a strong impact of fuel price in option 2, alternative 1 due to the higher overall fuel balance - overall fuel consumption. Impact of carbon dioxide cost is not so significant but,

Table 14. Total $\mathrm{CO}_{2}$ balance.

\begin{tabular}{|c|c|c|c|c|}
\hline Performance indicator & $\begin{array}{l}\mathrm{CHP} \text { before } \\
\text { repowering }\end{array}$ & $\begin{array}{l}\text { Repowering, } \\
\text { option no. } 1\end{array}$ & $\begin{array}{l}\text { Repowering, option } \\
\text { no. } 1 \text {, alt. } 1\end{array}$ & $\begin{array}{c}\text { Repowering, option } \\
\text { no. } 1 \text {, alt. } 2\end{array}$ \\
\hline $\mathrm{CO}_{2}$ production (kton year-1) & 746.87 & 717.37 & 758.39 & 717.20 \\
\hline $\mathrm{CHP}^{\prime} \mathrm{CO}_{2}$ production change (kton year ${ }^{-1}$ ) & - & -29.50 & +11.52 & -29.67 \\
\hline Net power production $\left(\mathrm{GWh}\right.$ year $\left.{ }^{-1}\right)$ & 507.70 & 580.54 & 806.25 & 769.62 \\
\hline Power production increase $\left(\mathrm{GWh}\right.$ year $\left.{ }^{-1}\right)$ & - & +72.84 & 298.55 & 261.92 \\
\hline \multicolumn{5}{|c|}{ Power production emission factor $=135.5 \mathrm{t} \mathrm{GWh}^{-1}[108]$} \\
\hline External $\mathrm{CO}_{2}$ emissions decrease (kton year ${ }^{-1}$ ) & 68.79 & 78.66 & 109.25 & 104.28 \\
\hline Total $\mathrm{CO}_{2}$ production $\left(\right.$ kton year $\left.{ }^{-1}\right)$ & 678.08 & 638.71 & 649.14 & 612.92 \\
\hline Total $\mathrm{CO}_{2}$ production change $\left(\right.$ kton year $\left.^{-1}\right)$ & - & -39.37 & -28.94 & -65.16 \\
\hline \multicolumn{5}{|c|}{ Power production emission factor $=800 \mathrm{t} \mathrm{GWh}^{-1}[109]$} \\
\hline External $\mathrm{CO}_{2}$ emissions decrease (kton year ${ }^{-1}$ ) & 406.16 & 464.43 & 645.00 & 615.70 \\
\hline Total $\mathrm{CO}_{2}$ production (kton year ${ }^{-1}$ ) & 340.71 & 252.94 & 113.39 & 101.5 \\
\hline Total $\mathrm{CO}_{2}$ production change (kton year ${ }^{-1}$ ) & - & -87.77 & -227.32 & -239.21 \\
\hline
\end{tabular}


with its anticipated increase to $100 € \mathrm{t}^{-1}$ in near future, it will certainly play an important role. Its increase is most beneficial for option 1. Escudero et al. [26] also identified $\mathrm{CO}_{2}$ cost as an important parameter in their economic model of industrial site repowering analysis.

Figs 6 and 7 show the results for prices lower (Fig. 6) and higher (Fig. 7) than base electricity prices. When comparing the trends in Fig. 5 to Fig. 7, higher electricity price is beneficial for all repowering options, which allows for payback periods as low as four years in some cases. The most significant impact on the payback period can be seen in repowering option 2, alternative 1 due to the highest achieved power production increase.

Figs 8 and 9 assess the impact of varying natural gas to $\mathrm{HFO}$ price ratio (in $€ \mathrm{GJ}^{-1}$ ). When comparing Fig. 5 with these figures, negative effect of increased
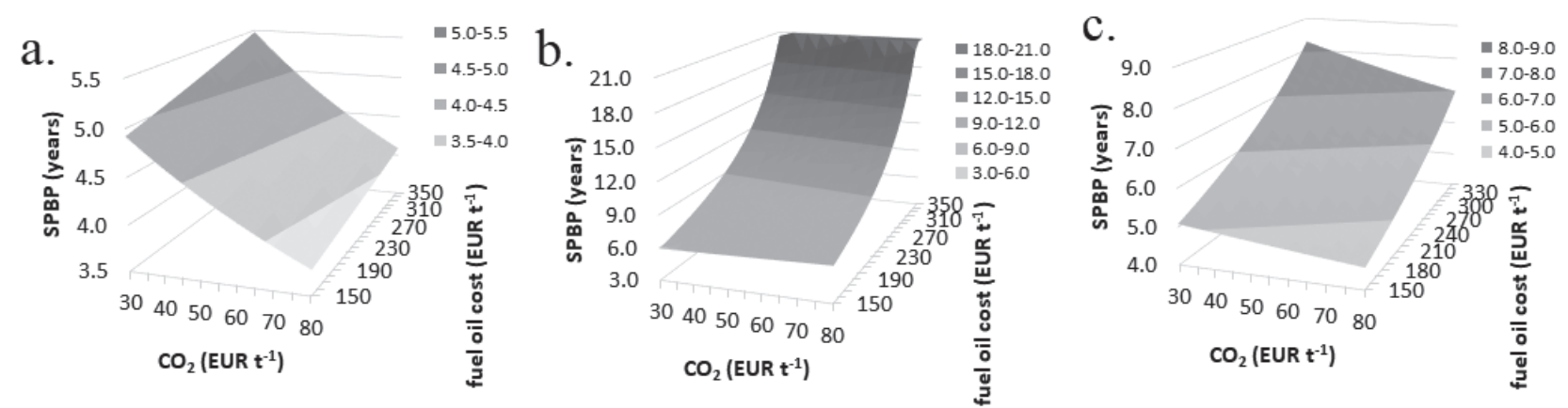

Fig. 5. Simple payback period (SPBP) dependence on carbon dioxide emissions cost and on fuel oil price considering electricity price of $55 € \mathrm{MWh}^{-1}$, and natural gas to fuel oil price ratio of $1: 1\left(€ \mathrm{GJ}^{-1}\right)$ for: a. repowering option No. 1; b. repowering option No. 2 alternative 1; c. repowering option No. 2 alternative 2 .
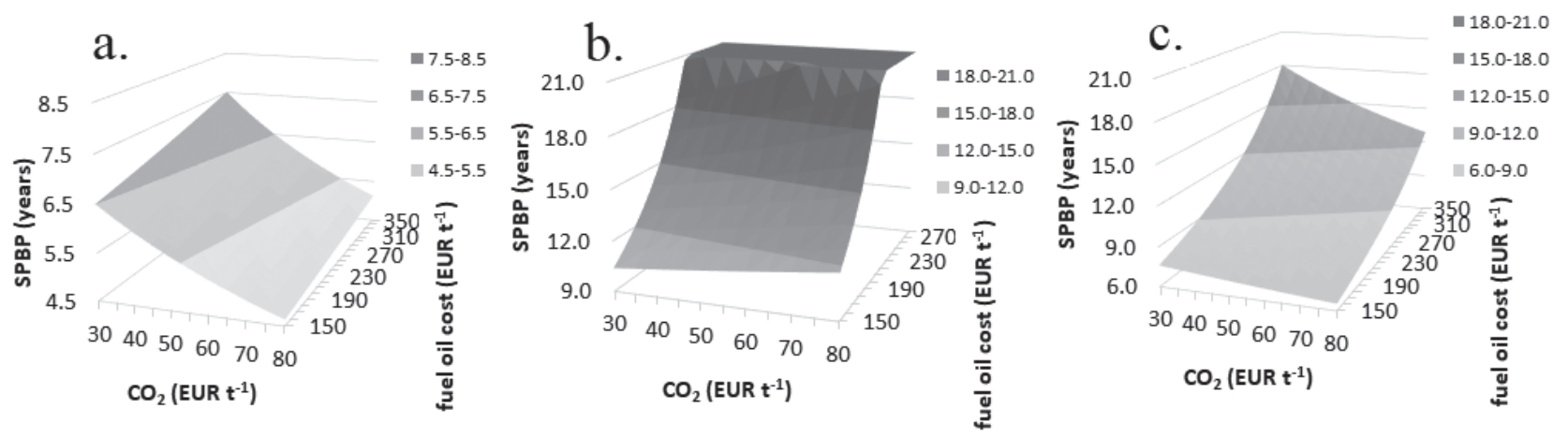

Fig. 6. Simple payback period (SPBP) dependence on carbon dioxide emissions cost and on fuel oil price considering electricity price of $40 € \mathrm{MWh}^{-1}$, and natural gas to fuel oil price ratio of $1: 1\left(€ \mathrm{GJ}^{-1}\right)$ for: a. repowering option No. 1; b. repowering option No. 2 alternative 1; c. repowering option No. 2 alternative 2 .
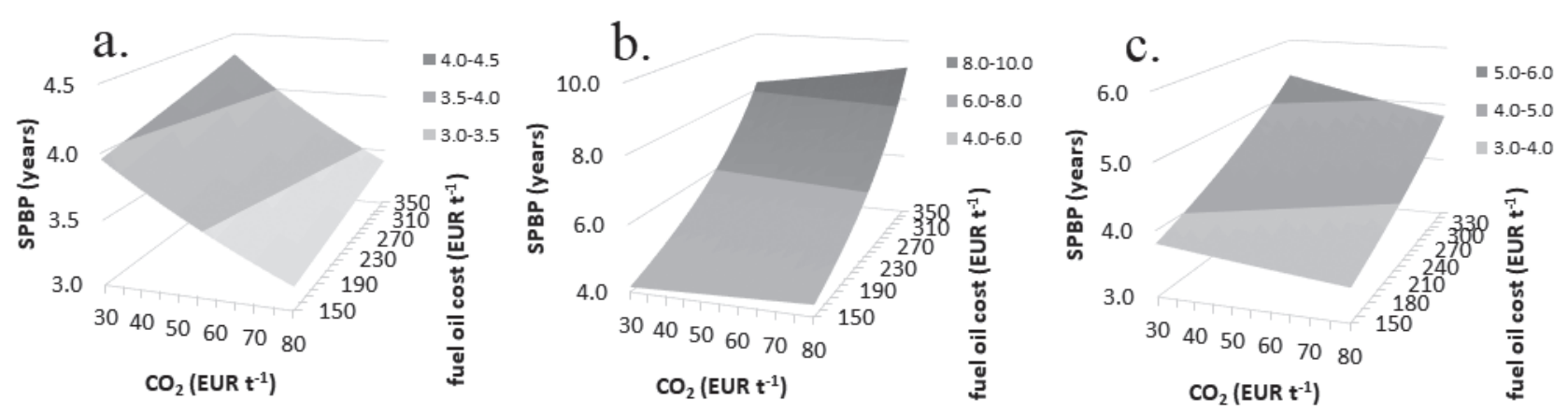

Fig. 7. Simple payback period (SPBP) dependence on carbon dioxide emissions cost and on fuel oil price considering electricity price of $70 € \mathrm{MWh}^{-1}$, and natural gas to fuel oil price ratio of $1: 1\left(€ \mathrm{GJ}^{-1}\right)$ for: a. repowering option No. 1; b. repowering option No. 2 alternative 1; c. repowering option No. 2 alternative 2. 

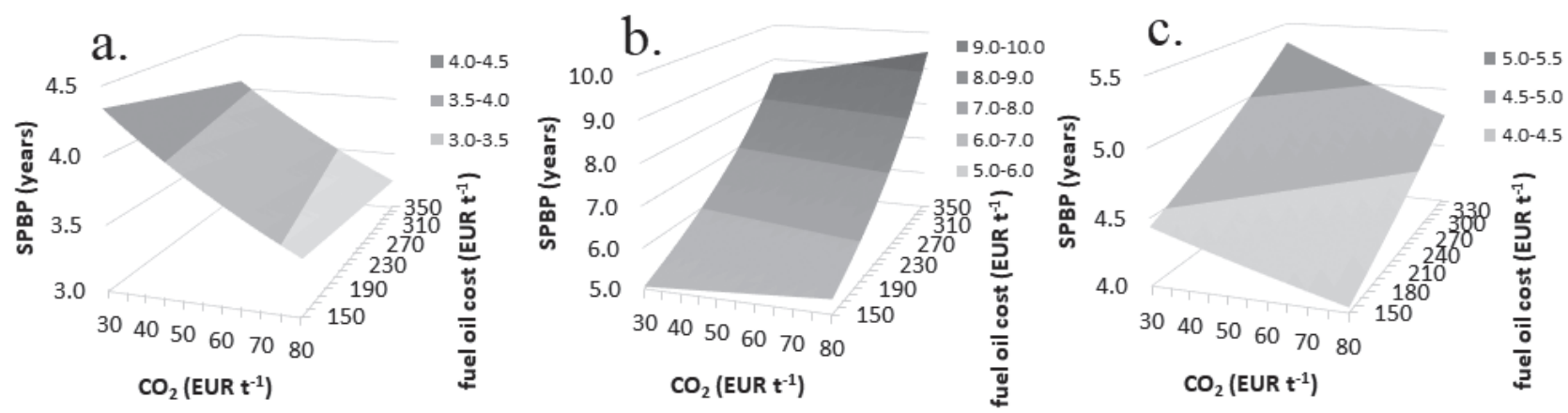

Fig. 8. Simple payback period (SPBP) dependence on carbon dioxide emissions cost and on fuel oil price considering electricity price of $55 € \mathrm{MWh}^{-1}$, and natural gas to fuel oil price ratio of 0.9:1 (€ GJ-1) for: a. repowering option No. 1; b. repowering option No. 2 alternative 1; c. repowering option No. 2 alternative 2 .
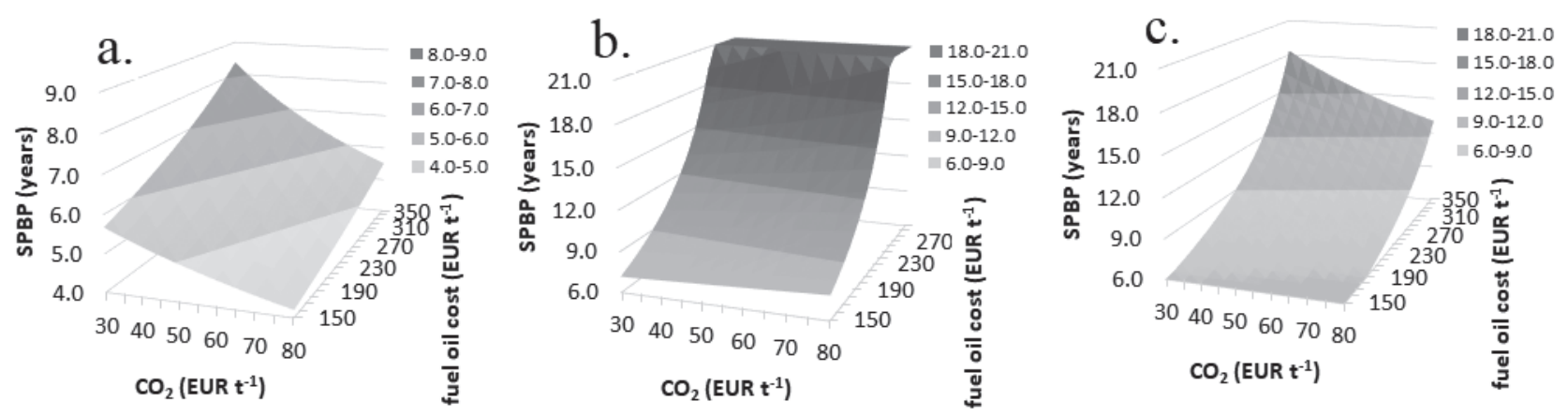

Fig. 9. Simple payback period (SPBP) dependence on carbon dioxide emissions cost and on fuel oil price considering electricity price of $55 € \mathrm{MWh}^{-1}$, and natural gas to fuel oil price ratio of 1.1:1 (€ GJ $\left.\mathrm{J}^{-1}\right)$ for: a. repowering option No. 1; b. repowering option No. 2 alternative 1; c. repowering option No. 2 alternative 2 .

natural gas price on simple payback periods can be seen in all repowering options. Even under these circumstances, repowering option 1 , as the most conservative one, offers reasonable economics, while option 2, alternative 1 is practically infeasible and alternative 2 is risky. This is an important finding, which reveals the sensitivity of more extensive repowering options to natural gas price and it further confirms that more conservative repowering options are more suitable for industrial CHPs.

\section{Overall Assessment}

Objectives of industrial CHP repowering differ from those in thermal power plants. More conservative solutions need to be adopted to achieve fuel consumption (fuel costs) reduction rather than significant power production increase. Extensive solutions widely applied in thermal power plants, which increase the power production capacity by $100 \%$ or even more are therefore not applicable in industrial CHP. Moreover, power production capacities by one or two orders of magnitude lower in industrial enterprises compared to large power plants, enable the application of new equipment (mostly gas turbines) of just modest power production efficiency ( 25 to $30 \%$ ) compared to that applied in advanced combined cycles. Considering these two facts, just a limited impact of industrial CHP repowering on its efficiency is expected.

As demonstrated in the presented study, solutions feasible from the energetic, economic, and environmental point of view comprise new power production equipment addition rather than replacement of the existing one. As a result, power production increases only modestly while the least effective means - condensing production in the existing steam turbine - is reduced to minimum. This in turn enables considerable reduction of carbon dioxide emissions as a high-carbon fuel (HFO) is partly replaced by a cleaner one (NG). Overall efficiency of the plant increases by several \%, depending also on the season of the year, which documents the need of industrial CHP repowering assessment from this viewpoint. Economic feasibility of the proposed repowering solutions strongly depends on fuel and electricity price relation as well as on carbon emissions cost. Its anticipated increase favors solutions reducing carbon emissions. Overall $\mathrm{CO}_{2}$ emissions assessment reveals the impact of power production emission factor selection and this aspect must not be omitted in repowering studies in general. 


\section{Conclusions}

Renovation and rehabilitation of industrial combined heat and power units remains out of the public and research spotlight. As to provide more insight into this matter, a model industrial sub-100 MW range CHP was set-up and verified, serving as the calculation basis for two gas turbine-based repowering options suitable for this type of power and heat source. The hot windbox option (option 1), is conservative, it requires smaller investment and leads to only modest changes in CHP operation and performance. A separate gas turbine with a heat recovery steam generator replacing a part of steam production is considered in option 2, with two alternatives depending on the HRSG design. This option leads to a significant increase in the CHP's power production and represents a more extensive (though not the most extensive) repowering option.

Option 1 leads to more efficient CHP operation compared to the base case in terms of power production efficiency. Significant seasonal effect on cogeneration efficiency was observed, which increased visibly in summer where repowering leads to a cut in condensing power production but decreased slightly in winter since condensing power production is minimal even before repowering. A net decrease in carbon dioxide emissions is achieved, which decreases further if emissions from external power production are considered. Option 2 reaches higher power production efficiency than option 1 and leads to minimized condensing power production. A substantial power production increase is achieved accompanied by a significant reduction of heavy fuel oil fired in the existing steam boiler. Depending on the alternative, either a slight increase or a modest decrease of carbon dioxide emissions is observed; incorporating external emissions led to a drop in overall emissions in all repowering options.

Economic assessment showed that the more conservative repowering option - hot windbox - offers shorter payback periods than other options and is less sensitive to the change in prices of energies and media, which is an advantage. Therefore, despite smaller achievable benefit compared to other options and considering its positive energetic and environmental evaluation it can be recommended as a viable solution for industrial CHPs.

\section{Acknowledgments}

This study was supported by the Slovak Research and Development Agency under the contracts No. APVV-18-0134 and APVV-19-0170.

\section{Conflict of Interest}

The authors declare no conflict of interest.

\section{References}

1. RISSMAN J., BATAILLE C., MASANET E., ADEN N., MORROW W.R., ZHOU N., ELLIOTT N., DELL R., HEEREN N., HUCKESTEIN B., CRESKO J., MILLER S.A., ROY J., FENNELL P., CREMMINS B., KOCH BLANK T., HONE D., WILLIAMS E.D., DE LA RUE DU CAN S., SISSON B., WILLIAMS M., KATZENBERGER J., BURTRAW D., SETHI G., PING H., DANIELSON D., LU H., LORBER T., DINKEL J., HELSETH J. Technologies and policies to decarbonize global industry: Review and assessment of mitigation drivers through 2070. Appl. Energy, 266, 114848, 2020.

2. HÁJEK M., ZIMMERMANNOVÁ J., HELMAN K., ROZENSKÝ L. Analysis of carbon tax efficiency in energy industries of selected EU countries. Energy Policy, 134, 110955, 2019.

3. GLAVIČ P., PINTARIČ Z.N., BOGATAJ M. Process Design and Sustainable Development - A European Perspective. Processes, 9 (1), 148, 2021.

4. BROŻYNA J., STRIELKOWSKI W., FOMINA A., NIKITINA N. Renewable Energy and EU 2020 Target for Energy Efficiency in the Czech Republic and Slovakia. Energies, 13 (4), 965, 2020.

5. REHFELDT M., FLEITER T., WORRELL E. Interfuel substitution in European industry: A random utility approach on industrial heat demand. J. Clean. Prod., 187, 98, 2018.

6. GERRES T., CHAVES ÁVILA J.P., LLAMAS P.L., SAN ROMÁN T.G. A review of cross-sector decarbonisation potentials in the European energy intensive industry. J. Clean. Prod., 210, 585, 2019.

7. FILIPPOV S.P., DIL'MAN M.D. CHP Plants in Russia: the Necessity for Technological Renovation. Therm. Eng., 65 (11), 775, 2018.

8. MONJARDINO J., DIAS L., FORTES P., TENTE H., FERREIRA F., SEIXAS J. Carbon Neutrality Pathways Effects on Air Pollutant Emissions: The Portuguese Case. Atmosphere, 12 (3), 324, 2021.

9. ȚIBULCĂ I. Reducing Air Pollution: Are Environmental Taxes Enough to Help the EU Member States Reach Climate Neutrality by 2050? Pol. J. Environ. Stud., 30 (5), 1, 2021.

10. CIESIELSKA-MACIĄGOWSKA D., KLIMCZAK D., SKRZEK-LUBASIŃSKA M. Central and Eastern European $\mathrm{CO}_{2}$ Market - Challenges of Emissions Trading for Energy Companies. Energies, 14 (4), 1051, 2021.

11. JIANG C., YUE Y. Sensitivity Analysis of Key Factors Influencing Carbon Prices under the EU ETS. Pol. J. Environ. Stud., 30 (4), 3645, 2021.

12. KEFFORD B.M., BALLINGER B., SCHMEDA-LOPEZ D.R., GREIG C., SMART S. The early retirement challenge for fossil fuel power plants in deep decarbonisation scenarios. Energy Policy, 119, 294, 2018.

13. KOCH K., ALT B., GADERER M. Dynamic Modeling of a Decarbonized District Heating System with CHP Plants in Electricity-Based Mode of Operation. Energies, 13 (16), 4134, 2020.

14. HAMELS S. $\mathrm{CO}_{2}$ Intensities and Primary Energy Factors in the Future European Electricity System. Energies, 14 (8), 2165, 2021.

15. GRAMMELIS P., KOUKOUZAS N., SKODRAS G., KAKARAS E., TUMANOVSKY A., KOTLER V. Refurbishment priorities at the Russian coal-fired power sector for cleaner energy production -Case studies. Energy Policy, 34 (17), 3124, 2006. 
16. QVIST S., GŁADYSZ P., BARTELA Ł., SOWIŻDŻAŁ A. Retrofit Decarbonization of Coal Power Plants - A Case Study for Poland. Energies, 14 (1), 120, 2020.

17. ZYŚK J., WYRWA A., SUWAŁA W., PLUTA M., OLKUSKI T., RACZYŃSKI $M$. The Impact of Decarbonization Scenarios on Air Quality and Human Health in Poland - Analysis of Scenarios up to 2050. Atmosphere, 11 (11), 1222, 2020.

18. ŠTOFOVÁ L., SZARYSZOVÁ P., MIHALČOVÁ B. Testing the Bioeconomic Options of Transitioning to Solid Recovered Fuel: A Case Study of a Thermal Power Plant in Slovakia. Energies, 14 (6), 1720, 2021.

19. ZELENAK S., SKVAREKOVA E., SENOVA A., WITTENBERGER G. The Usage of UCG Technology as Alternative to Reach Low-Carbon Energy. Energies, 14 (13), 3718, 2021.

20. KAZAGIC A., MUSIC M., SMAJEVIC I., ADEMOVIC A., REDZIC E. Possibilities and sustainability of "biomass for power" solutions in the case of a coal-based power utility. Clean Tech. Environ. Policy, 18 (6), 1675, 2016.

21. NUŢĂ F.M., NUŢĂ A.C., ZAMFIR C.G., PETREA S.M., MUNTEANU D., CRISTEA D.S. National Carbon Accounting - Analyzing the Impact of Urbanization and Energy-Related Factors upon $\mathrm{CO}_{2}$ Emissions in Central - Eastern European Countries by Using Machine Learning Algorithms and Panel Data Analysis. Energies, 14 (10), 2775, 2021.

22. KONDRAT'EVA O.E., ROSLYAKOV P.V., SKOBELEV D.O., GUSEVA T.V., LOKTIONOV O.A., ÅKE M. Developing the Cost-Estimation Technique When Switching to Best Available Power Technologies. Therm. Eng., 66 (7), 513, 2019.

23. WANG W., LI Z., LYU J., ZHANG H., YUE G., NI W. An overview of the development history and technical progress of China's coal-fired power industry. Front. Energy, 13 (3), 417, 2019.

24. RAVINA M., PANEPINTO D., ZANETTI M.C., GENON G. Environmental analysis of a potential district heating network powered by a large-scale cogeneration plant. Environ. Sci. Pollut. Res. Int., 24 (15), 13424, 2017.

25. GONZALEZ-SALAZAR M., LANGROCK T., KOCH C., SPIEß J., NOACK A., WITT M., RITZAU M., MICHELS A. Evaluation of Energy Transition Pathways to Phase out Coal for District Heating in Berlin. Energies, 13 (23), 6394, 2020.

26. ESCUDERO A.I., ESPATOLERO S., ROMEO L.M. Oxycombustion power plant integration in an oil refinery to reduce $\mathrm{CO}_{2}$ emissions. Int. J. Greenhouse Gas Control, 45, 118, 2016.

27. AHMADI G., TOGHRAIE D., AKBARI O. Energy, exergy and environmental (3E) analysis of the existing CHP system in a petrochemical plant. Renew. Sustain. Energy Rev., 99, 234, 2019.

28. VESELOV F.V., SOLYANIK A.I. Promotion of Investments in the Technological Renewal of the Thermal Power Industry. Stud. Russ. Econ. Dev., 30 (1), 28, 2019.

29. SKOCZKOWSKI T., BIELECKI S., WEGLARZ A., WLODARCZAK M., GUTOWSKI P. Impact assessment of climate policy on Poland's power sector. Mitig. Adapt. Strateg. Glob. Chang., 23 (8), 1303, 2018.

30. GÜNTHER M., GRELLER M., FALLAHNEJAD M. Evaluation of Long-Term Scenarios for Power Generation and District Heating at Stadtwerke München. InformatikSpektrum, 38 (2), 97, 2014.

31. KŘŮMAL K., MIKUŠKA P., HORÁK J., HOPAN F., KRPEC K. Comparison of emissions of gaseous and particulate pollutants from the combustion of biomass and coal in modern and old-type boilers used for residential heating in the Czech Republic, Central Europe. Chemosphere, 229, 51, 2019.

32. ROKNI M. Performance Comparison on Repowering of a Steam Power Plant with Gas Turbines and Solid Oxide Fuel Cells. Energies, 9 (6), 399, 2016.

33. WANG J., YOU S., ZONG Y., TRÆHOLT C., DONG Z.Y., ZHOU Y. Flexibility of combined heat and power plants: A review of technologies and operation strategies. Appl. Energy, 252, 113445, 2019.

34. COWELL R. The role of place in energy transitions: Siting gas-fired power stations and the reproduction of highcarbon energy systems. Geoforum, 112, 73, 2020.

35. GARCÍA S.G., MONTEQUÍN V.R., FERNÁNDEZ R.L., FERNÁNDEZ F.O. Evaluation of the synergies in cogeneration with steel waste gases based on Life Cycle Assessment: A combined coke oven and steelmaking gas case study. J. Clean. Prod., 217, 576, 2019.

36. MESFUN S., LEDUC S., PATRIZIO P., WETTERLUND E., MENDOZA-PONCE A., LAMMENS T., STARITSKY I., ELBERSEN B., LUNDGREN J., KRAXNER F. Spatiotemporal assessment of integrating intermittent electricity in the EU and Western Balkans power sector under ambitious $\mathrm{CO}_{2}$ emission policies. Energy, 164, 676, 2018.

37. TEPLICKÁ K., KOVÁČ M., ŠKVAREKOVÁ E., SEŇOVÁ A. Economic Life Cycle of Biomass Equipment and its Renovation. TEM J., 9 (4), 1419, 2020.

38. NYASHINA G.S., KURGANKINA M.A., STRIZHAK P.A. Environmental, economic and energetic benefits of using coal and oil processing waste instead of coal to produce the same amount of energy. Energy Convers. Manage., 174, 175, 2018.

39. ŠUHAJ P., HAYDARY J., HUSÁR J., STELTENPOHL P., ŠUPA I. Catalytic gasification of refuse-derived fuel in a two-stage laboratory scale pyrolysis/gasification unit with catalyst based on clay minerals. Waste Manage., 85, $1,2019$.

40. ROGALEV A., ROGALEV N., KINDRA V., KOMAROV I., ZLYVKO O. Research and Development of the OxyFuel Combustion Power Cycles with $\mathrm{CO}_{2}$ Recirculation. Energies, 14 (10), 2927, 2021.

41. JANUSZ-SZYMAŃSKA K., DRYJAŃSKA A. Possibilities for improving the thermodynamic and economic characteristics of an oxy-type power plant with a cryogenic air separation unit. Energy, 85, 45, 2015.

42. KOTOWICZ J., MICHALSKI S., BRZĘCZEK M. The Characteristics of a Modern Oxy-Fuel Power Plant. Energies, 12 (17), 3374, 2019.

43. DZURŇÁK R., JABLONSKÝ G., VARGA A., KIZEK J., PÁSTOR M., LUKÁČ L. Impact of oxygen enhanced combustion of natural gas on thermal efficiency of combustion aggregate. MATEC Web of Conferences, 168, $07016,2018$.

44. GHONIEM A.F., ZHAO Z., DIMITRAKOPOULOS G. Gas oxy combustion and conversion technologies for low carbon energy: Fundamentals, modeling and reactors. Proc. Combust. Inst., 37 (1), 33, 2019.

45. FOGARASI S., CORMOS C.-C. Assessment of coal and sawdust co-firing power generation under oxy-combustion conditions with carbon capture and storage. J. Clean. Prod., 142, 3527, 2017.

46. LIU Q., SHI Y., ZHONG W., YU A. Co-firing of coal and biomass in oxy-fuel fluidized bed for $\mathrm{CO}_{2}$ capture: A review of recent advances. Chin. J. Chem. Eng., 27 (10), 2261, 2019. 
47. ZAPOROWSKI B. Analysis of energy-conversion processes in gas-steam power-plants integrated with coal gasification. Appl. Energy, 74 (3-4), 297, 2003.

48. LECKNER B. Co-combustion: A summary of technology. Therm. Sci., 11 (4), 5, 2007.

49. WERLE S. A reburning process using sewage sludgederived syngas. Chem. Pap., 66 (2), 99, 2012.

50. KOČANOVÁ S., LUKÁČ L. The impact of the composition of the wood gas to emissions after combustion of wood gas. Holistic Approach Environ., 4 (3), 111, 2014.

51. BIANCHI M., BRANCHINI L., DE PASCALE A. Combining waste-to-energy steam cycle with gas turbine units. Appl. Energy, 130, 764, 2014.

52. CARAPELLUCCI R., GIORDANO L. Regenerative gas turbines and steam injection for repowering combined cycle power plants: Design and part-load performance. Energy Convers. Manage., 227, 113519, 2021.

53. ILIEV I.K., TERZIEV A.K., BELOEV H.I., NIKOLAEV I., GEORGIEV A.G. Comparative analysis of the energy efficiency of different types co-generators at large scales CHPs. Energy, 221, 119755, 2021.

54. AHMADI G., TOGHRAIE D., AKBARI O.A. Technical and environmental analysis of repowering the existing CHP system in a petrochemical plant: A case study. Energy, 159, 937, 2018.

55. VALAMIN A.E., KULTYSHEV A.Y., SHIBAEV T.L., GOL'DBERG A.A., STEPANOV M.Y. Heat flow diagrams with and without a deaerator for steam turbine plants with T-250/300-23.5 turbines. Therm. Eng., 63 (11), 777, 2016.

56. NIKBAKHT NASERABAD S., MEHRPANAHI A., AHMADI G. Multi-objective optimization of feedwater heater arrangement options in a steam power plant repowering. J. Clean. Prod., 220, 253, 2019.

57. YAO X., ZHOU H., XU K., XU Q., LI L. Evaluation of the fusion and agglomeration properties of ashes from combustion of biomass, coal and their mixtures and the effects of $\mathrm{K}_{2} \mathrm{CO}_{3}$ additives. Fuel, 255, 115829, 2019.

58. REHFELDT M., WORRELL E., EICHHAMMER W., FLEITER T. A review of the emission reduction potential of fuel switch towards biomass and electricity in European basic materials industry until 2030. Renew. Sustain. Energy Rev., 120, 109672, 2020.

59. HNYDIUK-STEFAN A., SKŁADZIEŃ J. Analysis of supercritical coal fired oxy combustion power plant with cryogenic oxygen unit and turbo-compressor. Energy, 128, 271, 2017.

60. LEI M., SUN C., WANG C. Techno-Economic Analysis of a $600 \mathrm{MW}$ Oxy-Enrich Pulverized Coal-Fired Boiler. Energies, 11 (4), 768, 2018.

61. MADSEN K., BENTSEN N. Carbon Debt Payback Time for a Biomass Fired CHP Plant - A Case Study from Northern Europe. Energies, 11 (4), 2018.

62. ONDREJKA HARBULAKOVA V., ZELENAKOVA M., PURCZ P., OLEJNIK A. Selection of the Best Alternative of Heating System by Environmental Impact Assessment - Case Study. Environments, 5 (2), 19, 2018.

63. RIMAR M., KULIKOVA O., KULIKOV A., FEDAK M. Energy Treatment of Solid Municipal Waste in Combination with Biomass by Decentralized Method with the Respect to the Negative Effects on the Environment. Sustainability, 13 (8), 4405, 2021.

64. ZIÓŁKOWSKI P., KOWALCZYK T., LEMAŃSKI M., BADUR J. On energy, exergy, and environmental aspects of a combined gas-steam cycle for heat and power generation undergoing a process of retrofitting by steam injection. Energy Convers. Manage., 192, 374, 2019.
65. COMODI G., LORENZETTI M., SALVI D., ARTECONI A. Criticalities of district heating in Southern Europe: Lesson learned from a CHP-DH in Central Italy. Appl. Therm. Eng., 112, 649, 2017.

66. JIMÉNEZ-ESPADAFOR AGUILAR F., GARCÍA M.T., TRUJILLO E.C., BECERRA VILLANUEVA J.A., FLORENCIO OJEDA F.J. Prediction of performance, energy savings and increase in profitability of two gas turbine steam generator cogeneration plant, based on experimental data. Energy, 36 (2), 742, 2011.

67. PETRENYA Y.K. Development of Gas Turbine Energy Technologies in Russia. Herald Russ. Acad. Sci., 89 (2), 101, 2019.

68. YILMAZOĞLU M.Z., DURMAZ A. Hot windbox repowering of coal-fired thermal power plants. Turk. J. Eng. Environ. Sci., 37, 33, 2013.

69. SANCHEZ DEL RIO M., GIBBINS J., LUCQUIAUD M. On the retrofitting and repowering of coal power plants with post-combustion carbon capture: An advanced integration option with a gas turbine windbox. Int. J. Greenhouse Gas Control, 58, 299, 2017.

70. TAŃCZUK M., SKOREK J., BARGIEL P. Energy and economic optimization of the repowering of coal-fired municipal district heating source by a gas turbine. Energy Convers. Manage., 149, 885, 2017.

71. NIKBAKHT NASERABAD S., MOBINI K., MEHRPANAHI A., ALIGOODARZ M.R. Exergy-energy analysis of full repowering of a steam power plant. Front. Energy, 9 (1), 54, 2015.

72. BARTNIK R., BURYN Z., HNYDIUK-STEFAN A., SZEGA M., POPŁAWSKI T. Power and Frequency Control in the National Power System of the 370 MW Coal Fired Unit Superstructured with a Gas Turbine. Energies, 13 (10), 2432, 2020.

73. DE PAEPE M., DICK E. Technological and economical analysis of water recovery in steam injected gas turbines. Appl. Therm. Eng., 21, 135, 2001.

74. GAMBINI M., VELLINI M., STILO T., MANNO M., BELLOCCHI S. High-Efficiency Cogeneration Systems: The Case of the Paper Industry in Italy. Energies, 12 (3), 335, 2019.

75. VARINY M., MIERKA O. Technologic, economic and exergoeconomic evaluation of proposed industrial heat and power plant revamp alternatives in an industrial company in Slovakia. Energy, 36 (1), 424, 2011.

76. MODESTO M., NEBRA S.A. Analysis of a repowering proposal to the power generation system of a steel mill plant through the exergetic cost method. Energy, 31 (15), $3261,2006$.

77. SLOVNAFT Heavy fuel oils, [cit. 6.5.2021]. Available at: https://slovnaft.sk/images/slovnaft/pdf/obchodni_partneri/ vyrobky/vykurovacie_oleje/vykurovaci_olej_tazky/ Vykurovaci_olej.pdf (in Slovak).

78. BAFRNCOVÁ S., ŠEFČÍKOVÁ M., VAJDA M., Chemické inžinierstvo: Tabul'ky a grafy (in Slovak). Vydavatel'stvo STU, Bratislava, Slovakia 2009; p 115.

79. WEATHER_AND_CLIMATE Climate in Bratislava (Bratislavský kraj), Slovakia, [cit. 6.5.2020]. Available at: https://weather-and-climate.com/average-monthlyRainfall-Temperature-Sunshinefahrenheit,Bratislava,Slov akia.

80. IBLER Z., KARTÁK J., MERTLOVÁ J., IBLER Z., Technický průvodce energetika (in Czech). Nakladatelství BEN- technická literatura: Praha, Czech Republic 2012; 615, 2012. 
81. MRZLJAK V., ANĐELIĆ N., LORENCIN I., SANDI BARESSI ŠEGOTA S. The influence of various optimization algorithms on nuclear power plant steam turbine exergy efficiency and destruction. Pomorstvo, 35 (1), 69, 2021.

82. STEVANOVIC V.D., WALA T., MUSZYNSKI S., MILIC M., JOVANOVIC M. Efficiency and power upgrade by an additional high pressure economizer installation at an aged 620 MWe lignite-fired power plant. Energy, 66, 907, 2014.

83. BARESSI ŠEGOTA S., LORENCIN I., ANĐELIĆ N., MRZLJAK V., CAR Z. Improvement of Marine Steam Turbine Conventional Exergy Analysis by Neural Network Application. J. Mar. Sci. Eng., 8 (11), 884, 2020.

84. MRZLJAK V., POLJAK I., MRAKOVČIĆ T. Energy and exergy analysis of the turbo-generators and steam turbine for the main feed water pump drive on LNG carrier. Energy Convers. Manage., 140, 307, 2017.

85. MEDICA-VIOLA V., BARESSI ŠEGOTA S., MRZLJAK V., ŠTIFANIĆ D. Comparison of conventional and heat balance based energy analyses of steam turbine. Pomorstvo, 34 (1), 74, 2020.

86. CIUKAJ S., PRONOBIS M. Dew Point of the Flue Gas of Boilers Co-Firing Biomass with Coal. Chem. Process Eng., 34 (1), 101, 2013.

87. OKKES A.G. Get acid dew point of flue gas. Hydrocarbon Processing, 66 (7), 53, 1987.

88. SPP-DISTRIBÚCIA. Natural gas quality in 2020. Available online: https://www.sppdistribucia.sk/wpcontent/uploads/2021/01/Kvalita_ZP_emisny_faktor_ sk_2020.pdf. (Accessed on 1303 2021) [in Slovak].

89. KIM T.S., RO S.T. Effect of Control Modes and Turbine Cooling on the Part Load Performance in the Gas Turbine Cogeneration System. Heat Recovery Syst. CHP, 15 (3), 281, 1995.

90. SPIRAXSARCO. Steam tables. Available online: https:// www.spiraxsarco.com/resources-and-design-tools/steamtables/sub-saturated-waterregion\#article-top. (Accessed on $21102020)$.

91. ESMAP. Study of Equipment Prices in the Power Sector. Available online: https://esmap.org/sites/default/files/ esmap-files/TR12209_GBL_Study_of_Equipment Prices_in_the_Power_Sector.pdf. (Accessed on 2304 2021).

92. NASERABAD S.N., MEHRPANAHI A., AHMADI G. Multi-objective optimization of HRSG configurations on the steam power plant repowering specifications. Energy, 159, 277, 2018.

93. National Bank of Slovak Republic. Exchange rates. Available online: https://www.nbs.sk/sk. (Accessed on 30 04 2021).

94. CEPCI. Chemical Engineering Plant Cost Index value for 2019. Available online: https://www.scribd.com/ document/464061207/2019-CEPCI. (Accessed on 2604 2021).

95. HACKL R., HARVEY S. Identification, cost estimation and economic performance of common heat recovery systems for the chemical cluster in Stenungsund. Project report, Available online: https://publications.lib.chalmers. se/records/fulltext/187164/187164.pdf., 2013. (Accessed on 2304 2021).

96. LIPTÁKOVÁ E., RIMÁR M., KIZEK J., ŠEFČÍKOVÁ Z. The Evolution of Natural Gas Prices in EU Countries and their Impact on the Country's Macroeconomic Indicators. Civ. Environ. Eng. Rep., 31 (2), 255, 2021.
97. Bunker. World Bunkers Prices. Available online: https:// shipandbunker.com/prices. (Accessed on 2604 2021).

98. EMBER. Daily carbon prices. Available online: https:// ember-climate.org/data/carbon-price-viewer/. (Accessed on 0107 2021).

99. URSO. Consumer prices of electric energy. Available online: http://www.urso.gov.sk/?q=Pre $\% 20$ spotrebite $\% \mathrm{C} 4 \% \mathrm{BEa} /$ Burzov\%C3\%A $\% \% 20$ ceny $\% 20$ elektriny\%20a \%20plynu. (Accessed on 2604 2021) [in Slovak].

100. LIESKOVSKÝ M., TRENČIANSKY M., MAJLINGOVÁ A., JANKOVSKÝ J. Energy Resources, Load Coverage of the Electricity System and Environmental Consequences of the Energy Sources Operation in the Slovak Republic - An Overview. Energies, 12 (9), 1701, 2019.

101. CHEN L., WEMHOFF A.P. Predicting embodied carbon emissions from purchased electricity for United States counties. Appl. Energy, 292, 116898, 2021.

102. HAMELS S., HIMPE E., LAVERGE J., DELGHUST M., VAN DEN BRANDE K., JANSSENS A., ALBRECHT J. The use of primary energy factors and $\mathrm{CO}_{2}$ intensities for electricity in the European context - A systematic methodological review and critical evaluation of the contemporary literature. Renew. Sustain. Energy Rev., 146, 111182, 2021.

103. HUBER J., LOHMANN K., SCHMIDT M., WEINHARDT C. Carbon efficient smart charging using forecasts of marginal emission factors. J. Clean. Prod., 284, 124766, 2021.

104. LEERBECK K., BACHER P., JUNKER R.G., TVEIT A., CORRADI O., MADSEN H., EBRAHIMY R. Control of Heat Pumps with $\mathrm{CO}_{2}$ Emission Intensity Forecasts. Energies, 13 (11), 2851, 2020.

105. JANÍČEK F., PONIČAN J., SADLOŇ M. Impact of the fixed and variable component of electricity price on the economic viability of a small-scale photovoltaic power plant. J. Electr. Eng., 72 (2), 140, 2021.

106. REHMAN H.U., HIRVONEN J., JOKISALO J., KOSONEN R., SIRÉN K. EU Emission Targets of 2050: Costs and $\mathrm{CO}_{2}$ Emissions Comparison of Three Different Solar and Heat Pump-Based Community-Level District Heating Systems in Nordic Conditions. Energies, 13 (16), 4167, 2020.

107. SECKINGER N., RADGEN P. Dynamic Prospective Average and Marginal GHG Emission FactorsScenario-Based Method for the German Power System until 2050. Energies, 14 (9), 2527, 2021.

108. VARINY M., JEDINÁ D., KIZEK J., ILLÉS P., LUKÁČ L., JANOŠOVSKÝ J., LESNÝ M. An Investigation of the Techno-Economic and Environmental Aspects of Process Heat Source Change in a Refinery. Processes, 7 (11), 776, 2019.

109. FARQUHARSON D., JARAMILLO P., SCHIVLEY G., KLIMA K., CARLSON D., SAMARAS C. Beyond Global Warming Potential: A Comparative Application of Climate Impact Metrics for the Life Cycle Assessment of Coal and Natural Gas Based Electricity. J. Ind. Ecol., 21 (4), 857, 2017.

110. VARINY M., JEDINÁ D., RIMÁR M., KIZEK J., KŠIŇANOVÁ M. Cutting Oxygen Production-Related Greenhouse Gas Emissions by Improved Compression Heat Management in a Cryogenic Air Separation Unit. International Journal of Environmental Research and Public Health, 18 (19), 10370, 2021. 